\title{
The value of soil respiration measurements for interpreting and modeling terrestrial carbon cycling
}

\author{
Claire L. Phillips • Ben Bond-Lamberty • Ankur R. Desai • Martin Lavoie • \\ Dave Risk • Jianwu Tang $\cdot$ Katherine Todd-Brown $•$ Rodrigo Vargas
}

Received: 24 June 2016 / Accepted: 7 October 2016 / Published online: 16 November 2016

(C) Springer International Publishing Switzerland 2017

\begin{abstract}
Background An acceleration of model-data synthesis activities has leveraged many terrestrial carbon datasets, but utilization of soil respiration $\left(\mathrm{R}_{\mathrm{S}}\right)$ data has not kept pace. Scope We identify three major challenges in interpreting $\mathrm{R}_{\mathrm{S}}$ data, and opportunities to utilize it more extensively and creatively: (1) When $R_{S}$ is compared to ecosystem respiration $\left(\mathrm{R}_{\mathrm{ECO}}\right)$ measured from $\mathrm{EC}$ towers, it is not uncommon to find $R_{S}>R_{E C O}$. We argue this is most likely due to difficulties in calculating $\mathrm{R}_{\mathrm{ECO}}$, which provides an opportunity to utilize $\mathrm{R}_{\mathrm{S}}$ for EC quality control. (2) $R_{S}$ integrates belowground heterotrophic and autotrophic activity, but many models include only an explicit heterotrophic output. Opportunities exist to use the total
\end{abstract}

The original version of this article was revised: This paper was published with incorrect Figs. 8 and 9 as they are swapped. Fig. 8 should be Fig. 9 and vice versa.

Responsible Editor: Philippe Hinsinger.

C. L. Phillips $(\bowtie)$

Department of Crops and Soil Science, Agriculture and Life

Sciences Building, Oregon State University, Corvallis, OR 97331, USA

e-mail: claire.phillips@ oregonstate.edu

B. Bond-Lamberty

Pacific Northwest National Laboratory, Joint Global Change

Research Institute, College Park, MD 20740, USA

A. R. Desai

Department of Atmospheric and Oceanic Sciences, University of Wisconsin, Madison, WI 53706, USA
$\mathrm{R}_{\mathrm{S}}$ flux for data assimilation and model benchmarking methods rather than less-certain partitioned fluxes. (3) $R_{S}$ is generally measured at a very different resolution than that needed for comparison to $\mathrm{EC}$ or ecosystem- to global-scale models. Downscaling EC fluxes to match the scale of $R_{S}$, and improvement of $R_{S}$ upscaling techniques will improve resolution challenges.

Conclusions $\mathrm{R}_{\mathrm{S}}$ data can bring a range of benefits to model development, particularly with larger databases and improved data sharing protocols to make $\mathrm{R}_{\mathrm{S}}$ data more robust and broadly available to the research community.

Keywords Soil respiration · Data-model fusion . Carbon $\cdot \mathrm{CO}_{2}$

M. Lavoie · D. Risk

Department of Earth Sciences, St. Francis Xavier University, Antigonish, NS B2G 2WA, Canada

J. Tang

The Ecosystems Center, Marine Biological Laboratory, Woods Hole, MA 02543, USA

K. Todd-Brown

Biological Sciences, Pacific Northwest National Laboratory, Richland, WA 99352, USA

R. Vargas

Department of Plant and Soil Sciences, University of Delaware, Newark, DE 19716, USA 


\section{Nomenclature}

Aboveground $\mathrm{R}_{\mathrm{A}}$

Aboveground autotrophic respiration (foliage + stem + fruit + aerial root + epiphyte respiration)

Belowground $\mathrm{R}_{\mathrm{A}} \quad$ Autotrophic soil respiration (root + rhizosphere + mycorrhizae respiration)

$\begin{array}{ll}\text { EC } & \text { Eddy covariance } \\ \text { GPP } & \text { Gross primary production } \\ \text { NEE } & \text { Net ecosystem exchange; an } \\ & \text { instantaneous CO2 flux measured } \\ & \text { by the eddy covariance method } \\ & (\text { GPP + RECO) } \\ & \text { Net ecosystem production } \\ & \text { (cumulative annual NEE, or } \\ \text { NEP } & \left.\text { NPP - } R_{H}\right) \\ & \text { Net primary production; the } \\ & \text { annual growth of plants above } \\ \text { NPP } & \text { and belowground } \\ & \text { Heterotrophic soil respiration } \\ & \text { Soil respiration (belowground } \\ \mathrm{R}_{\mathrm{H}} & \text { RA }+ \text { RH) } \\ \mathrm{R}_{\mathrm{S}} & \text { Ecosystem respiration } \\ & \text { (RS + aboveground RA) } \\ \text { RECO } & \text { Soil organic matter } \\ & \text { Total belowground carbon flux } \\ \text { SOM } & \text { (belowground NPP + belowground } \\ \text { TBCF } & \text { RA + change in SOM) }\end{array}$

\section{Introduction}

Measures of soil respiration $\left(\mathrm{R}_{\mathrm{S}}\right.$, the flux of $\mathrm{CO}_{2}$ between the soil surface and atmosphere) extending over the last $60+$ years constitute a geographically and ecologically rich dataset that has improved our understanding of soil carbon (C) cycling. For example, metaanalyses have used these data to draw inferences about the correlation between $\mathrm{R}_{\mathrm{S}}$ and its biotic and abiotic drivers (Raich and Schlesinger 1992); the autotrophic and heterotrophic sources of $\mathrm{R}_{\mathrm{S}}$ (Bond-Lamberty et al. 2004; Subke et al. 2006); the importance of $\mathrm{CO}_{2}$ production and biophysical lags to $\mathrm{R}_{\mathrm{S}}$ patterns (Vargas et al. 2010a); the response of the global $R_{S}$ flux to climate change (Carey et al. In review; Bond-Lamberty and Thomson 2010; Wang et al. 2014; Zhou et al. 2016); the temperature sensitivity of soil heterotrophic respiration (Zhou et al. 2009; Wang et al. 2014); and the response of $R_{S}$ flux to experimental changes in precipitation patterns (Thomey et al. 2011; Vicca et al. 2014). For specific sites, $R_{S}$ has also been used to calculate biometric-based estimates of carbon exchange in comparison with eddy covariance data (Curtis et al. 2002; Gough et al. 2008; Goulden et al. 2011; Giasson et al. 2013), providing a powerful constraint on carboncycle measurements and modeling.

In spite of this progress, the terrestrial carbon cycle remains a remarkably uncertain component of Earth system models (ESMs), an uncertainty that has been primarily attributed to the soil component (Friedlingstein et al. 2006; Todd-Brown et al. 2013; Anav et al. 2013; Friedlingstein et al. 2014; Hoffman et al. 2014). Many fundamental questions about climate change depend on the sensitivity of $R_{S}$ to global change factors, including whether soils will gain or lose $\mathrm{C}$ over the next century (Cox et al. 2013; Todd-Brown et al. 2014), how the residence time of terrestrial $\mathrm{C}$ will change (Schuur et al. 2009; Giardina et al. 2014; Carvalhais et al. 2014), and whether mitigation actions can sequester soil $\mathrm{C}$ in meaningful quantities, and over meaningful timeframes for human societies (Paustian et al. 2016). Although researchers recognize the central importance of soils to C-climate feedbacks (Ciais et al. 2013), and are aware of the thousands of extant data on seasonal and annual fluxes (BondLamberty and Thomson 2010), $\mathrm{R}_{\mathrm{S}}$ data are rarely used for these models' parameterization or assessment (Shao et al., 2013).

There are several reasons why $R_{S}$ data are infrequently used. First, many recent efforts to improve the representation of soil $\mathrm{C}$ turnover in ESMs have focused on simulations at decadal to millennial timescales, and therefore on improving model fidelity of variables that integrate long time periods, such as soil $\mathrm{C}$ stocks and ${ }^{14} \mathrm{C}$ ages (ToddBrown et al. 2012; Koven et al. 2013; Wieder et al. 2013; Todd-Brown et al. 2014). In contrast, when daily to annual $\mathrm{C}$ fluxes are simulated, there is often a bias towards utilizing eddy covariance (EC) flux data to the exclusion of other data streams partially because of the readily accessible EC data (Williams et al. 2009; Richardson et al. 2010; Kuppel et al. 2012; Keenan et al. 2013; Collalti et al. 2016). Second, while $R_{S}$ seasonal and annual sums have been compiled (Bond-Lamberty and Thomson 2010; 
Hashimoto 2012), instantaneous $R_{S}$ measures from autochambers and survey campaigns have rarely been synthesized (Bahn et al. 2010; Vargas et al. 2010a; Lavoie et al. 2014; Cueva et al. 2015), and are not easily available to modelers because they are not in organized data repositories (see Vargas and Leon 2015 for an exception). These small but geographically widespread datasets are generally in the hands of individual investigators, and are part of what Dietze et al. (2013) refers to as the 'long tail' of data. Third, many scientists are not sure how to use $\mathrm{R}_{\mathrm{S}}$ data effectively. The relationship between $\mathrm{R}_{\mathrm{S}}$ and soil $\mathrm{C}$ stocks and turnover is not always conceptually clear, particularly given uncertainties in partitioning $\mathrm{R}_{\mathrm{S}}$ sources. $\mathrm{R}_{\mathrm{S}}$ also does not match one-to-one with soil heterotrophic respiration $\left(\mathrm{R}_{\mathrm{H}}\right)$, which is the variable generally desired for modeling soil $C$ turnover, but rather integrates $R_{H}$ and belowground autotrophic respiration $\left(\mathrm{R}_{\mathrm{A}}\right)$. The fact that $\mathrm{R}_{\mathrm{S}}$ integrates multiple processes - root and microbial activity, along a vertical gradient of soil activity - can make $R_{S}$ a challenging flux to interpret and represent in mathematical models (Vargas et al. 2011b).

Given the rapid development of new soil $\mathrm{C}$ cycle representations in ESMs (Luo et al., 2016), these $R_{S}$ data represent an underutilized resource, as $R_{S}$ is an information-rich data stream that occupies an important mid-level spatial scale bridging soil pore-scale processes to ecosystem-scale fluxes (Fig. 1). Other ecosystemscale measures, such as net primary production (NPP) and net ecosystem production (NEP), similarly integrate multiple processes (e.g., respiration and photosynthesis, from both subcanopy and canopy layers), but nonetheless have been used effectively for model validation and improvement (Hudiburg et al. 2009; Williams et al. 2009; Schwalm et al. 2010; Keenan et al. 2012).

The goal of this review is to highlight the opportunities for utilizing $\mathrm{R}_{\mathrm{s}}$ data, justify continued collection of these data, and inspire novel synthesis and modeling activities. We highlight three challenges for utilizing and interpreting $\mathrm{R}_{\mathrm{S}}$, and identify potential solutions. We then discuss how $R_{S}$ data are useful for model development, and outline approaches for using $R_{S}$ for data-model fusion (i.e. selecting models and parameters that are ecologically realistic and consistent with a range of data streams) and for model benchmarking (ranking models by how well they match observations). We also discuss quality control and database activities that will make $\mathrm{R}_{\mathrm{S}}$ data more robust, useful, and broadly available to the scientific research community.

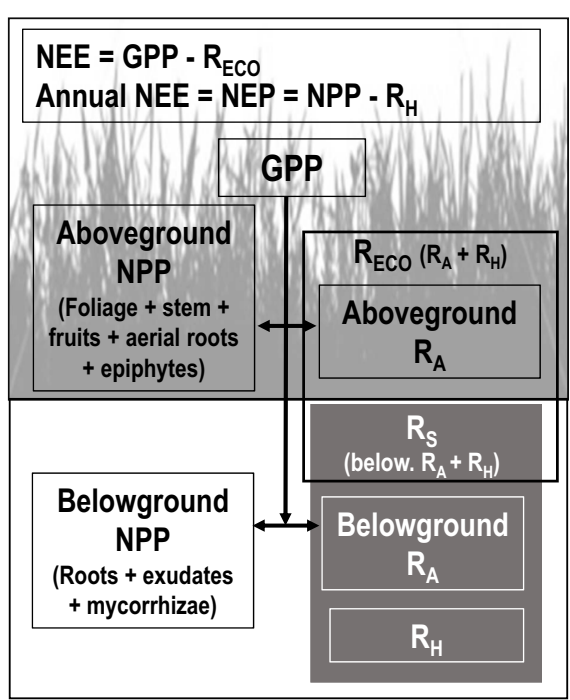

Fig. 1 Schematic of ecosystem $\mathrm{C}$ budget components. Gross primary production (GPP) is allocated to above and belowground plant growth (net primary production, NPP) and respiration $\left(\mathrm{R}_{\mathrm{A}}\right)$. Total soil respiration $\left(R_{S}\right)$ is the sum of belowground $R_{A}$ and heterotrophic respiration $\left(\mathrm{R}_{\mathrm{H}}\right)$. Total ecosystem respiration $\left(\mathrm{R}_{\mathrm{ECO}}\right)$ includes $\mathrm{R}_{\mathrm{s}}$ plus aboveground $\mathrm{R}_{\mathrm{A}}$. Net ecosystem exchange (NEE) is the $\mathrm{CO}_{2}$ flux measured by the eddy covariance method, and generally reported on a $30 \mathrm{~min}$ basis. Cumulative annual NEE is called net ecosystem production (NEP) and represents the net increase or decrease in ecosystem carbon storage. NEP can also be estimated from biomass-based measures of plant growth and chamber-based measures of $\mathrm{R}_{\mathrm{H}}$

\section{Challenge 1: reconciling soil and tower fluxes}

The $\mathrm{R}_{\mathrm{S}}-\mathrm{R}_{\mathrm{ECO}}$ mismatch

At many EC tower sites, particularly in forests, studies have reported periods when $\mathrm{R}_{\mathrm{S}}$ is consistently higher than ecosystem respiration $\left(\mathrm{R}_{\mathrm{ECO}}\right)$ (Phillips et al. 2010; Thomas et al. 2013; Giasson et al. 2013; Speckman et al. 2015). This is biophysically impossible: $R_{S}$ is a major component of whole-ecosystem respiration in forests, but it cannot be higher than $\mathrm{R}_{\mathrm{ECO}}$, which also includes stem, leaf, and other aboveground autotrophic respiration (Bolstad et al., 2004; Gough et al. 2008; Ohkubo et al., 2007; Tang et al. 2008). This irregularity indicates either inconsistent measurement footprints, or persistent measurement biases in $\mathrm{R}_{\mathrm{ECO}}, \mathrm{R}_{\mathrm{S}}$, or both (Fig. 2).

This challenge was first identified nearly 20 years ago, with $\mathrm{R}_{\mathrm{S}}$ measurements reported to be higher than $R_{E C O}$ in boreal forests (Lavigne et al. 1997). While $R_{S}$ has measurement errors and scaling issues (see Table 1 and Challenge 3), systematic underestimation of $\mathrm{R}_{\mathrm{ECO}}$ is now believed to affect 


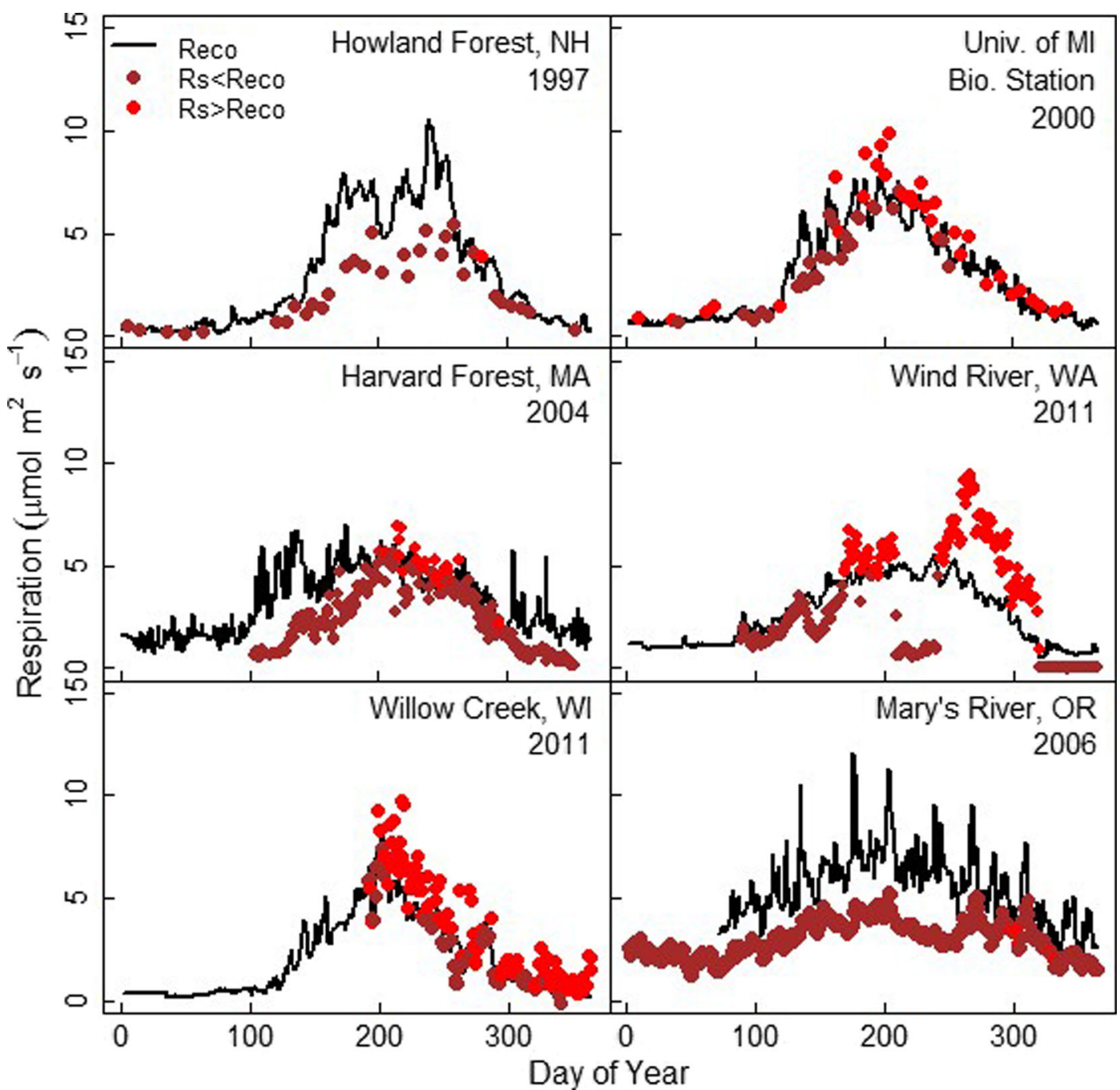

Fig. 2 Comparison of $\mathrm{R}_{\mathrm{ECO}}$ (Level 4 FLUXNET estimates) and $R_{S}$ at four forested eddy covariance sites. $R_{S}>R_{E C O}$ for significant periods at Harvard Forest, Wind River, and Willow Creek. By

practically all EC sites (Schimel et al. 2008; Aubinet et al. 2012). For instance, Luyssaert et al. (2007) conducted a global synthesis of forest $\mathrm{C}$ flux and pools, and showed that non-closure of ecosystem $\mathrm{C}$ budgets was the rule rather than the exception. As much as $60 \%$ of the $\mathrm{CO}_{2}$ thought to be taken up by forests based on EC-based GPP was unallocated to plant biomass. Indirect evidence also comes from EC energy balance studies, which have shown that more energy enters EC sites than can be accounted for by latent and sensible heat losses, suggesting that some $\mathrm{CO}_{2}$ emissions might also be missed (Falge et al. 2001; e.g. Barr et al. 2006; Papale et al. 2006; Franssen et al. 2010; Foken et al. 2011; Stoy et al. 2013). contrast, at Mary's River site a subcanopy flux system was used to identify and gap-fill nights with decoupling, improving $\mathrm{R}_{\mathrm{ECO}}$ estimates (Thomas et al. 2013)

One common explanation is the influence of advection on net ecosystem exchange (NEE) measurements using EC. This implies that we should have more confidence in high $\mathrm{R}_{\mathrm{ECO}}$ values, while lower values should be rejected as they have higher probability of being affected by advection or other systematic errors (Van Gorsel et al. 2007). Several studies in forest ecosystems have attributed $\mathrm{R}_{\mathrm{ECO}}-\mathrm{R}_{\mathrm{S}}$ mismatch to $\mathrm{EC}$ measurements that are affected by topography, which influences advection and thus calculation of NEE (Kutsch et al. 2008; Phillips et al. 2010). In tall plant canopies, nocturnal fluxes can also be difficult to measure because of poorly constrained storage of $\mathrm{CO}_{2}$ within canopies, assumptions for low turbulence 
Table 1 Sources of uncertainty for chamber-based $\mathrm{R}_{\mathrm{S}}$ and EC-based $\mathrm{R}_{\mathrm{ECO}}$ measurements

\begin{tabular}{|c|c|c|}
\hline Source of uncertainty & Magnitude & References \\
\hline \multicolumn{3}{|l|}{ EC tower } \\
\hline Propagated instrumentation uncertainty & $1-3 \%$ & $\begin{array}{l}\text { Loescher et al. (2006), Schmidt et al. } \\
\text { (2012), Xu et al. (2017) }\end{array}$ \\
\hline Random error & $\begin{array}{l}\text { 6-19\%, function of flux magnitude } \\
\text { (heteroskedastic) }\end{array}$ & $\begin{array}{l}\text { Richardson et al. (2006), Finkelstein and } \\
\text { Sims (2001) }\end{array}$ \\
\hline Day/night differences in respiration rate & $\mathrm{R}_{\mathrm{ECO}} 6-20 \%$ lower during daytime & Falge et al. (2002) \\
\hline $\begin{array}{l}\text { Day/night differences in measurement } \\
\text { footprint (location bias) }\end{array}$ & $5-24 \%$ & Chen et al. (2011) \\
\hline Low turbulence & $3-27 \%$ & Foken (2008) \\
\hline Advection & $5-20 \%$ & Falge et al. (2001), Aubinet et al. (2003) \\
\hline $\mathrm{R}_{\mathrm{ECO}}$ method & $10 \%$ & Lasslop et al. (2012), Desai et al. (2008) \\
\hline Gap filling & $7 \%$ & Desai et al. (2008) \\
\hline Other decoupling processes & Unknown & $\begin{array}{l}\text { Aubinet et al. (2003), Cook et al. (2004), } \\
\text { Aubinet et al. (2012) }\end{array}$ \\
\hline \multicolumn{3}{|l|}{ Soil chamber } \\
\hline Chamber system measurement error & $30 \%$ & Pumpanen et al. (2004) \\
\hline Random error & $20 \%$ of flux magnitude (heteroskedastic) & $\begin{array}{l}\text { Lavoie et al. (2014), Savage et al. (2008), } \\
\text { Cueva et al. (2015) }\end{array}$ \\
\hline Wind advection & $233 \%$ in unvented chambers & Bain et al. (2005) \\
\hline Missed subniveal fluxes & $35-28 \%$ & Monson et al. (2006) \\
\hline Soil collar damage to fine roots & $15 \%$ & Heinemeyer et al. (2011) \\
\hline $\begin{array}{l}\text { Scaling up to tower footprint (spatial } \\
\text { variability) }\end{array}$ & Unknown & \\
\hline
\end{tabular}

filtering (i.e., $\mathrm{u}^{*}$ threshold), and decoupling of eddy covariance systems from subcanopy processes (Goulden et al. 1996; Aubinet and Feigenwinter 2010; Thomas et al. 2013; e.g. Alekseychik et al. 2013).

Mismatch may also occur when $\mathrm{R}_{\mathrm{ECO}}$ is much larger than $\mathrm{R}_{\mathrm{S}}$, for example as reported by Giasson et al. (2013) during winter at Harvard Forest. In this case, the large difference between $\mathrm{R}_{\mathrm{ECO}}$ and $\mathrm{R}_{\mathrm{S}}$ indicated high rates of aboveground respiration, approximately twice as large as soil respiration. This is improbable, given that deciduous trees dominate the site. Again, the difficulty in reconciling EC and soil measures may result from poor vertical air mixing. For quality assurance, time periods with low wind or turbulent conditions are generally filtered from NEE time series, but if high winds ventilate the snowpack where $\mathrm{CO}_{2}$ from soil respiration has been accumulating, then such windy periods could produce over-estimates of $\mathrm{R}_{\mathrm{ECO}}$.

The tendency for nocturnal NEE (and hence $\mathrm{R}_{\mathrm{ECO}}$ based on common approaches) to be underestimated results in artificially high estimates of gap-filled annual net ecosystem production (NEP), and can also cause ecosystem responses to global change factors to be missed. In a dramatic example, Speckman et al. (2015) compared chamber and tower-based estimates of $\mathrm{R}_{\mathrm{ECO}}$ over seven growing seasons during a bark beetle infestation that reduced live wood biomass by $85 \%$ at the GLEES Ameriflux site in Wyoming (Fig. 3). Over that period, EC-based estimates of $\mathrm{R}_{\mathrm{ECO}}$ did not change, while chamber-based estimates of $\mathrm{R}_{\mathrm{ECO}}$ declined by $35 \%$. Importantly, the mismatch between tower and chamber-based measurements was not dependent on turbulence, and did not diminish when more restrictive turbulence filtering criteria $\left(\mathrm{u}^{*}\right)$ were used. However, the mismatch did diminish over time with increasing tree mortality, leading the authors to conclude that the loss of canopy improved coupling of flows between the subcanopy and within-canopy air space.

In addition to measurement limitations, there are algorithmic limitations to estimating $\mathrm{R}_{\mathrm{ECO}}$ with EC. Importantly, $\mathrm{R}_{\mathrm{ECO}}$ and GPP are not directly measuredthey are inferred as the result of partitioning NEE. Most 

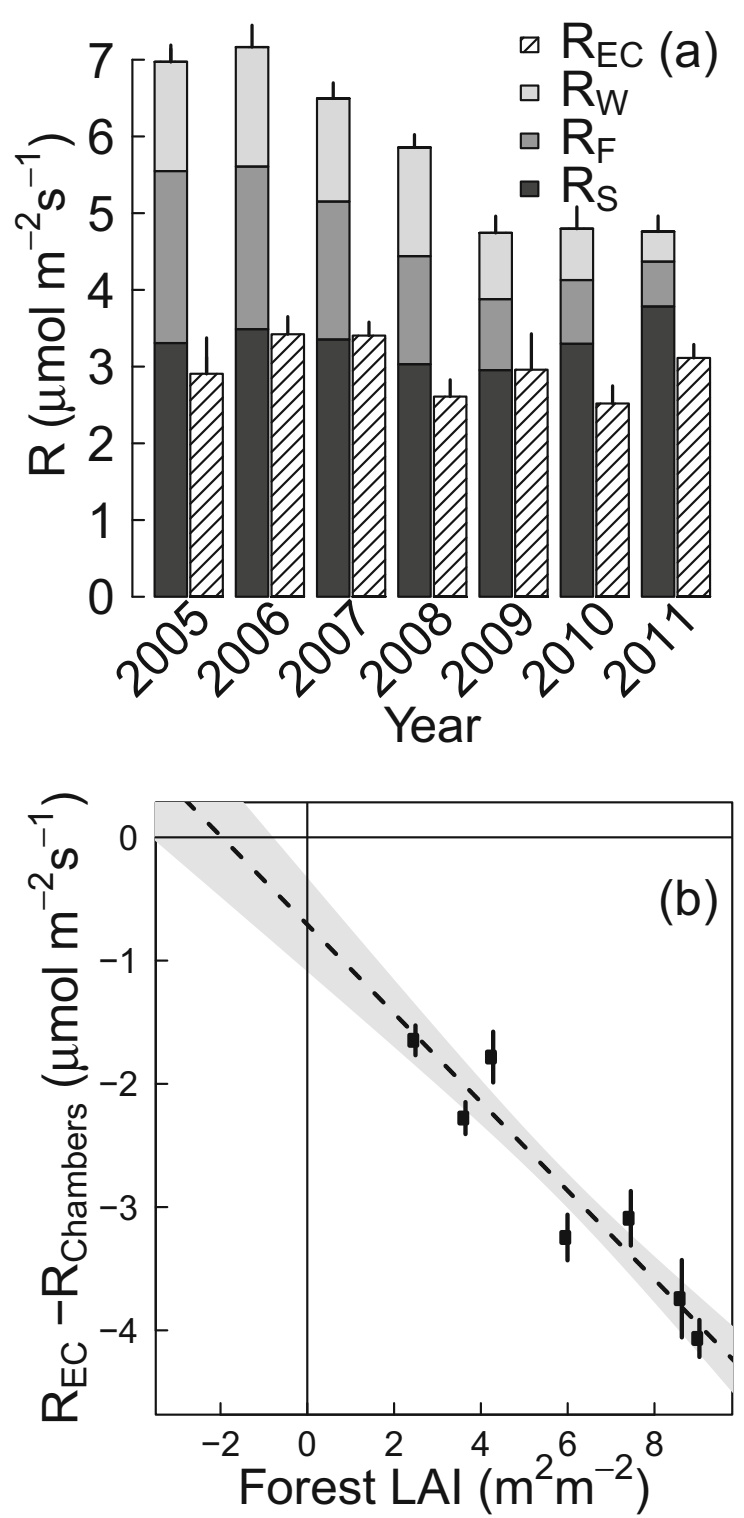

Fig. 3 Comparison of chamber and tower based estimates of $\mathrm{R}_{\mathrm{ECO}}$ at the GLEES Ameriflux site during a massive bark beetle die-off. a Comparison of $\mathrm{R}_{\mathrm{ECO}}$ measured by $\mathrm{EC}\left(\mathrm{R}_{\mathrm{EC}}\right)$, and by summed chamber measures of stems $\left(\mathrm{R}_{\mathrm{W}}\right)$, foliage $\left(\mathrm{R}_{\mathrm{F}}\right)$, and soil $\left(\mathrm{R}_{\mathrm{S}}\right)$. Chamber and tower mismatch correlated with canopy leaf area index (LAI). Reprinted with permission from Speckman et al. (2015)

partitioning approaches rely on the assumption that NEE at night, when photosynthetically active radiation is low or zero, does not have GPP, and that the drivers of $\mathrm{R}_{\mathrm{ECO}}$ (primarily temperature) and GPP (primarily light) differ. Most partitioning methods also assume that nighttime $\mathrm{R}_{\mathrm{ECO}}$ is a good proxy for daytime $\mathrm{R}_{\mathrm{ECO}}$, or vice versa. However, linkages between photosynthesis rate and soil autotrophic and heterotrophic activity (Tang et al. 2005; Carbone et al. 2007; Bahn et al. 2009; Vargas et al. 2012), diurnal patterns of soil moisture available to soil heterotrophs (Baker et al. 2008), and diurnally shifting tower footprints (Xu et al. 2017), all lead to potential mismatch between $R_{S}$ and $R_{E C O}$. Furthermore, recent methods for estimating daytime respiration using light-response relationships (Laslop et al. 2010) or stable-isotope approaches (Wehr et al. 2016), have shown that $R_{E C O}$ is lower during day than at night, due to photoinhibition of leaf respiration. By providing daytime measurements of $\mathrm{R}_{\mathrm{ECO}}$, these methods also allow partitioning of GPP and $\mathrm{R}_{\mathrm{ECO}}$ in situations with low nocturnal turbulence, or with advection, will hopefully yield better fit between $R_{S}$ and $\mathrm{R}_{\mathrm{ECO}}$ in the future.

The preceding examples demonstrate that EC, while a powerful approach, has particular limitations and biases. Franks et al. (1997) cautioned against calibrating models exclusively with EC flux data, a point reiterated by Medlyn et al. (2005) and Keenan et al. (2013). Nevertheless, there is a heavy reliance on EC estimates of GPP and $\mathrm{R}_{\mathrm{ECO}}$ for model development and benchmarking, a practice that amounts to fitting models to models.

Opportunities to close the $\mathrm{R}_{\mathrm{S}}-\mathrm{R}_{\mathrm{ECO}}$ gap

Given that simultaneous chamber-based $\mathrm{R}_{\mathrm{S}}$ measurements are already collected at many EC sites, it would be relatively easy to use comparisons of $\mathrm{R}_{\mathrm{ECO}}$ and $\mathrm{R}_{\mathrm{S}}$ to flag potentially low-quality EC data (Tang et al. 2008; Phillips et al. 2010; Giasson et al. 2013). Based on Ameriflux sites contributing $\mathrm{R}_{\mathrm{S}}$ data the Ameriflux database or to the Soil Respiration Database (BondLamberty and Thomson 2010), we estimate $R_{S}$ data are available for at least 37 sites.

While continuous measurements are ideal, even intermittent data provide valuable constraints on $\mathrm{R}_{\mathrm{ECO}}$. First, $\mathrm{R}_{\mathrm{S}}$ data constitutes an independent measurement, which is important for methodology validation. Second, $R_{S}$ measures are not subject to systematic biases at night due to low turbulence conditions (although $R_{S}$ chamber bias can occur under high turbulence conditions, e.g. Takle et al. (2004)). Third, $\mathrm{R}_{\mathrm{S}}$ is directly measured rather than inferred. Fourth, the accuracy of soil chamber measurements is technically straightforward to measure using a sand column with a known flux rate, a type of calibration check that is not possible for EC (Martin et al. 2004; 
Pumpanen et al. 2004; Risk et al. 2011). Laboratory calibration has the potential to make $R_{S}$ data, at least in theory, more accurate than $\mathrm{R}_{\mathrm{ECO}}$. For instance, Pumpanen et al. (2004) compared twenty different $R_{S}$ chambers on a sand column through which a known $\mathrm{CO}_{2}$ flux rate was established. They found substantial variation based on chamber design, ranging approximately $\pm 35 \%$ from the true flux rate, indicating that there is unrealized potential to reduce $R_{S}$ uncertainty by using sand columns more widely for routine soil chamber calibration. Such systems can also be used to test chamber responses to wind and changes in soil moisture under laboratory conditions. Sand column calibration cannot account all sources of error and bias, such as soil collar damage roots and hyphae (Heinemeyer et al. 2011), but provides considerable constraint on instrumentation uncertainty (Table 1).

We suggest using $\mathrm{R}_{\mathrm{S}}-\mathrm{R}_{\mathrm{ECO}}$ comparison as an alternative evaluation of EC data quality, in addition to energy balance closure and more traditional metrics such as $\mathrm{u}^{*}$. (One of the largest uncertainties associated with this, upscaling chamber measurements to the EC tower footprint, is discussed below in Challenge 3.) There are several examples of utilizing $\mathrm{R}_{\mathrm{S}}$ to detect low-quality nocturnal EC fluxes, and to construct bottom-up, chamber-based estimates (combining soil, stem and foliage respiration) to gap-fill $\mathrm{R}_{\mathrm{ECO}}$ under periods of flow decoupling and advection (Van Gorsel et al. 2009; Zeeman et al. 2012; Thomas et al. 2013; Alekseychik et al. 2013; Speckman et al. 2015). Alternatively, Thomas et al. (2013) were able to salvage a large portion of nocturnal EC measures at a site prone to advection by summing above-canopy fluxes with fluxes inferred from a sub-canopy system and soil chambers.

Ultimately, uncertainty analyses are likely to reveal sites and periods where EC $\mathrm{R}_{\mathrm{ECO}}$ fluxes are difficult to reconcile with other techniques. Therefore, it may be necessary to move away from the customary approach of gap-filling and partitioning EC flux data, toward more use of the best observations-EC data from optimal conditions, or chamber-based data-for model evaluations.

\section{Challenge 2: beyond autotrophic and heterotrophic partitioning}

Terrestrial ecosystem models rarely simulate $R_{S}$ explicitly, but instead simulate components of $\mathrm{R}_{\mathrm{H}}$ and $\mathrm{R}_{\mathrm{A}}$. In some cases, aboveground and belowground components of $\mathrm{R}_{\mathrm{A}}$ may be pooled into a single flux (e.g. CLM: Oleson et al. 2010), roots may be lumped with aboveground biomass, as is the case in some simple models (e.g., DALEC: Williams et al. 2005 or SIPNET: Braswell et al. 2005), or respiration flux components may be output in ways difficult to combine into an estimate of modeled $R_{S}$ that is truly comparable to observed $\mathrm{R}_{\mathrm{S}}$. For this reason, and because $\mathrm{R}_{\mathrm{H}}$ is used in conjunction with NPP to estimate annual terrestrial $C$ storage (NEP, see Fig. 1), total $R_{S}$ is often not as useful to modelers as its partitioned components. But partitioning $R_{S}$ is non-trivial, requiring experimental manipulations that are prone to artifacts (Hanson et al. 2000; Kuzyakov 2006; Subke et al. 2006). Most partitioning experiments, whether they utilize isotopes or bulk fluxes, require physically separating roots from native soil, and doing so alters moisture, temperature, oxygen levels, and $\mathrm{C}$ source-sink dynamics from the undisturbed system, all of which likely influence $R_{A}$ and $\mathrm{R}_{\mathrm{H}}$ estimates (Nickerson and Risk 2009; Phillips et al. 2013; Snell et al. 2014). Furthermore, there is ample evidence that microbial 'priming', i.e. enhancement of microbial decomposition due to root growth, is likely the rule rather than the exception, making $R_{H}$ and $\mathrm{R}_{\mathrm{A}}$ conjoined fluxes that can only be artificially disentangled (Zhu and Cheng 2011; Dijkstra et al. 2013; Qiao et al. 2014; Finzi et al. 2015).

Because of these obstacles, are there alternatives to traditional partitioning approaches that can be used as model constraints? One well-established approach for using aggregate, unpartitioned $\mathrm{R}_{\mathrm{S}}$ to constrain component processes is the Total Belowground Carbon Flux (TBCF) approach, originally proposed by Raich and Nadelhoffer (1989). This method indirectly estimates plant belowground $\mathrm{C}$ allocation $\left(\mathrm{R}_{\mathrm{A}}+\right.$ belowground NPP, see Fig. 1) using measurements of $R_{S}$ and litter fluxes. The TBCF approach makes several major assumptions to justify indirect estimation of plant allocation, namely that most $\mathrm{C}$ leaves the soil through respiration (i.e. dissolved $\mathrm{C}$ losses and erosion are negligible), and that net changes in standing litter and SOM are negligible. The TBCF approach has been criticized for poor correlation with direct observations in managed forest systems (Gower et al. 1996), but nevertheless has generated important insights into plant allocation when applied at a global-scale (Litton et al. 2007; Litton and Giardina 2008). In addition to employing TCBF,we argue there are more opportunities to use measured aggregate $R_{S}$ to validate the sum of the separately modeled $R_{H}$ 
and $\mathrm{R}_{\mathrm{A}}$. Furthermore, while partitioning studies will continue to be important, there are also opportunities to improve on them to obtain much more detail, for instance by applying techniques that allow more than two sources of $\mathrm{R}_{\mathrm{S}}$ to be resolved.

Partitioning $\mathrm{R}_{\mathrm{S}}$ - what has been learned?

Researchers have attempted to partition $\mathrm{R}_{\mathrm{S}}$ into discrete sub-fluxes for decades (Coleman 1973), with a few studies almost a hundred years old (Lundegårdh 1927; Turpin 1920). Attributing $R_{S}$ to its source components furthers our mechanistic understanding of the many processes underlying and controlling this large $\mathrm{C}$ flux (Luo and Zhou 2006). In addition, after ecosystem-scale theories of $\mathrm{C}$ and energy dynamics were developed (Kira and Shidei 1967; Odum 1969), isolating the heterotrophic component of $\mathrm{R}_{\mathrm{S}}$ allowed, in conjunction with a measure of net primary production, computation of ecosystem carbon gain or loss $\left(\mathrm{NEP}=\mathrm{NPP}-\mathrm{R}_{\mathrm{H}}\right.$, see Fig. 1). Finally, once it was realized that $R_{S}$ components might respond differently to environmental drivers and climate change (Boone et al. 1998), partitioning experiments were critical to draw generalized inferences in these areas (Wang et al. 2014).

A number of meta-analyses and syntheses have attempted to distill what has been learned from decades of partitioning experiments. Hanson et al. (2000) gave a qualitative assessment of partitioning methods and found that published studies exhibited wide variability, but on average about half ( $46 \%$ ) of the annual $\mathrm{R}_{\mathrm{S}}$ flux was rootderived. Using significantly larger data sets, BondLamberty et al. (2004) and Subke et al. (2006) found that as $R_{S}$ increases, autotrophic contributions increase more than heterotrophic contributions; this pattern is generally consistent across biomes and different ecosystem ages; and there are no significant differences between partitioning methods (Kuzyakov 2006). Finally, two recent meta-analyses have explored how climate warming (Wang et al. 2014) and the interactive effect of multiple global change factors (Zhou et al. 2016) affect $R_{S}$ and its components. Importantly, these studies have found differences in response timing and magnitude, with $R_{H}$ exhibiting a sustained response to warming versus a non-significant $\mathrm{R}_{\mathrm{A}}$ response. They have also shown that complex interactive effects between factors such as warming, elevated $\mathrm{CO}_{2}$, and nitrogen addition can even reverse the direction of response (Zhou et al. 2016).
An interesting question is how and when global relationships for partitioning $R_{S}$ can be used, particularly as more than a decade has passed since the original global analyses of $\mathrm{R}_{\mathrm{H}}$, and almost an order of magnitude more studies have been published partitioning $\mathrm{R}_{\mathrm{S}}$. To examine this question, we took data from a global soil respiration database (Bond-Lamberty and Thomson 2010), computed $R_{H}$ via two well-known published equations (Bond-Lamberty et al. 2004; Subke et al. 2006), and computed the resulting error relative to the known, measured $\mathrm{R}_{\mathrm{H}}$ flux in the database (Fig. 4). From 386 studies, only 121 reported $R_{H}$ fluxes within $\pm 10 \%$ of the equation-derived value, while large errors occurred in ecosystems with anomalously-low $R_{H}$ values (but note that these high percentage errors represent very low absolute numbers); no relationship with biome, ecosystem type, or time since disturbance was evident. This emphasizes the caution researchers must use when applying such generalized equations to singular locations, in particular in areas with high nitrogen deposition (Janssens et al., 2010) or suspected imbalances (from e.g., recent disturbance) in the soil carbon cycle (Harmon et al. 2011). Because direct measurements of $\mathrm{R}_{\mathrm{A}}$ and $\mathrm{R}_{\mathrm{H}}$ are have not been collected for many C-budget study sites (Luyssaert et al. 2007; Litton and Giardina 2008), there may be temptation to downscale global equations where no better measurements are available. However, C-budget

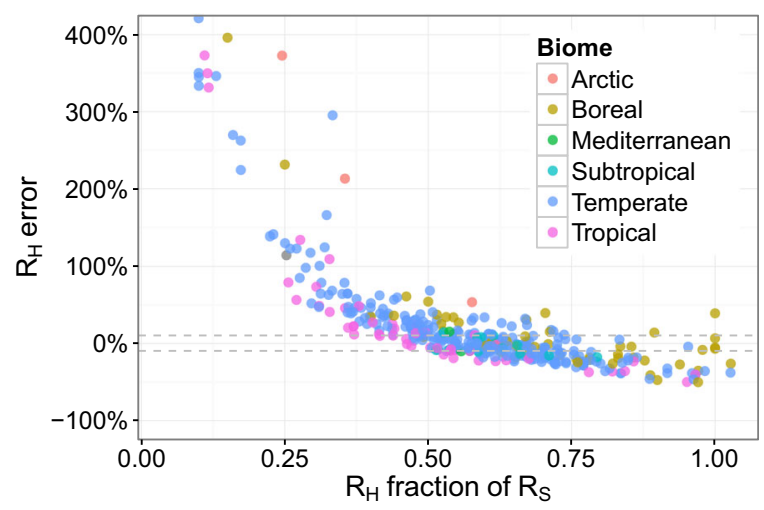

Fig. 4 Error arising from application of global relationships to partition sources of soil respiration. Data from a global soil respiration database, filtered to studies reporting both $R_{S}$ and $R_{H}$ from unmanipulated ecosystems. $\mathrm{R}_{\mathrm{H}}$ was computed from $\mathrm{R}_{\mathrm{S}}$ following Bond-Lamberty et al. (2004) and compared to reported $\mathrm{R}_{\mathrm{H}}$; dashed lines show $\pm 10 \%$ error. Data based on Subke et al. (2006) are almost identical and not shown. These global relationships predict that the $R_{H}$ fraction of $R_{S}$ decreases as $R_{S}$ increases, but do not allow for sites with high $R_{S}$ and very low $R_{H}$ (at upper left; the graph cuts off a few very high-error sites) 
relationships derived from large aggregates of data can add considerable error when applied at local scales (Kicklighter et al. 1994; Gower et al. 1996).

Opportunity: advancing partitioning to consider more than two sources

Partitioning experiments have generated important insights, but designing experiments around a two-source model of $\mathrm{R}_{\mathrm{S}}$ is both a conceptual and physical limitation. There are many cases in which it is useful to partition $\mathrm{R}_{\mathrm{S}}$ into three or more sources, for instance to distinguish decomposition of recent soil $\mathrm{C}$ additions from that of native soil $\mathrm{C}$ and $\mathrm{R}_{\mathrm{A}}$ (Whitman and Lehmann 2015), or to separate out the contribution of mycorrhizae from roots and free-living microbes (Heinemeyer et al. 2007; Heinemeyer et al. 2011; Phillips et al. 2012; Barba et al. 2016). As climate and land-use change disrupt equilibrium soil conditions, it becomes more important to partition microbial decomposition of older, stored $\mathrm{C}$ in addition to labile $\mathrm{C}$ (Wutzler and Reichstein 2007). By applying multiple partitioning approaches simultaneously-for instance physically separating roots as well as monitoring the isotopic composition of each component (Czimczik et al. 2006; Hopkins et al. 2013; Phillips et al. 2013), using different-sized micropore mesh treatements (Moyano et al. 2007; Heinemeyer et al. 2007), using two gas tracers simultaneously (Risk et al. 2013b), or combining single tracer experiments in which different $\mathrm{C}$ sources are isotopically labelled in each experiment (Whitman and Lehmann 2015)-it becomes possible to characterize more than two components of $\mathrm{R}_{\mathrm{S}}$.

Until recently, many researchers simply equated $R_{A}$ with being from 'recent' $\mathrm{C}$ sources, and $\mathrm{R}_{\mathrm{H}}$ with being from 'older' C sources, as depicted in Fig. 5a (Högberg et al. 2001; Hahn et al. 2006; Ogle and Pendall 2015). However, a number of studies have demonstrated that the $C$ age of $R_{A}$ and $R_{H}$ varies at seasonal to interannual timescales as depicted in Fig. 5b. For instance, compiling root-respired ${ }^{14} \mathrm{CO}_{2}$ data from three temperate forests, Hopkins et al. (2013) showed a tendency for $\mathrm{R}_{\mathrm{A}}$ to include substantial $\mathrm{C}$ from previous years early in the growing season, transitioning to current-year $\mathrm{C}$ by the end of summer (Fig. 6). Similarly, Lynch et al. (2013) showed that after the cessation of a free air $\mathrm{CO}_{2}$ enrichment experiment,

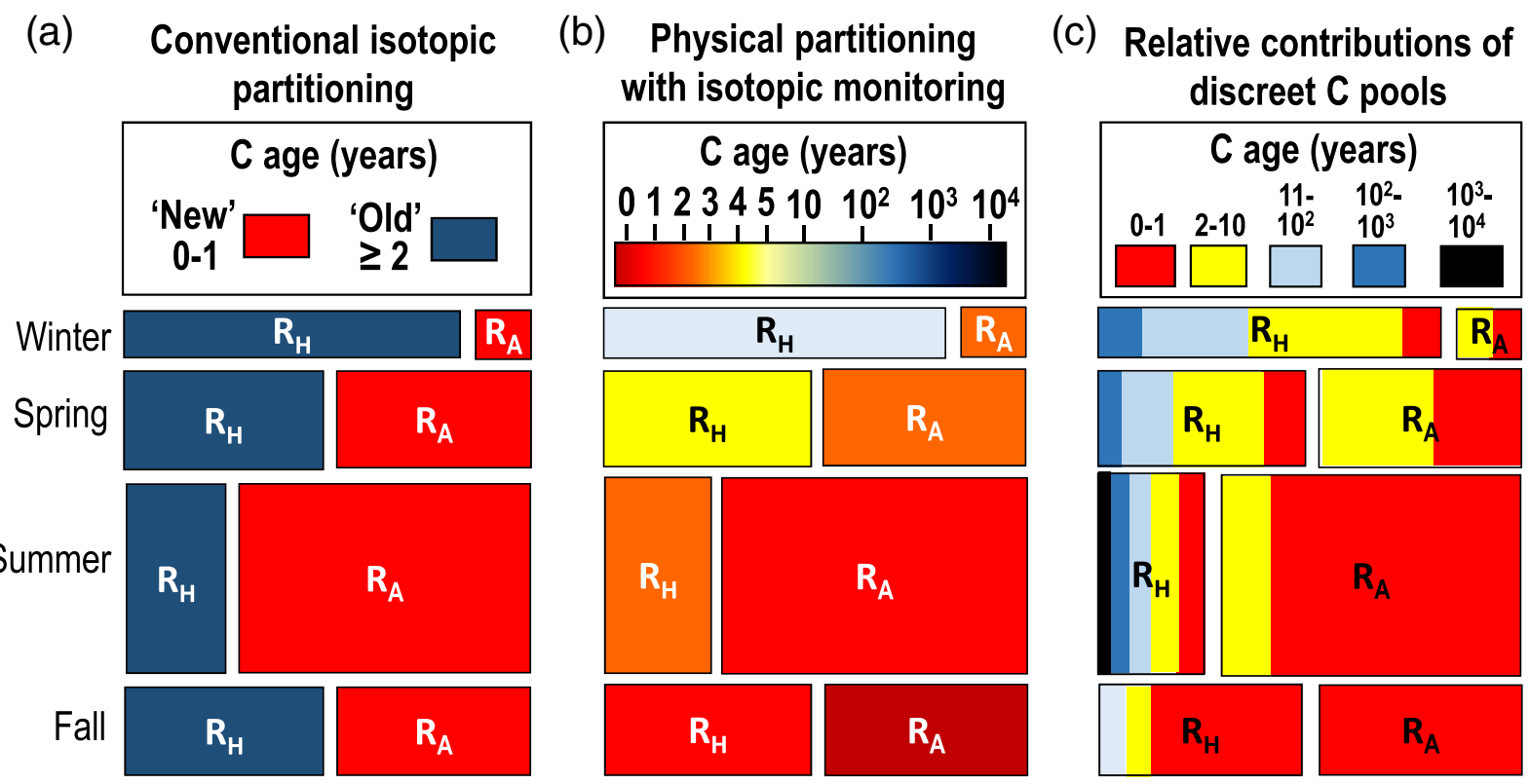

Fig. 5 Combining ${ }^{14} \mathrm{C}$ monitoring or ${ }^{13} \mathrm{C}$ pulse-chase labeling with physical partitioning provides observations that are more useful for testing model $\mathrm{C}$ pool structures. a An isotope mixing model for partitioning $R_{S}$, which assumes new $C$ is from $R_{A}$ and old $\mathrm{C}$ is from $\mathrm{R}_{\mathrm{H}}$. b By using physical partitioning methods such as root exclusion while also monitoring the isotopic composition of each component, dynamic ages have been observed at seasonal to interannual timescales. In this example, both $\mathrm{R}_{\mathrm{H}}$ and $\mathrm{R}_{\mathrm{A}}$ include more 'new' $\mathrm{C}$ as the growing season progresses. c Age determinations of $R_{A}$ and $R_{H}$ can be used to test models simulating $C$ as discreet pools with characteristic turnover times. In this example, five soil $\mathrm{C}$ pools and two plant $\mathrm{C}$ pools are represented, and turnover of both very old and new $\mathrm{C}$ increased during summer 


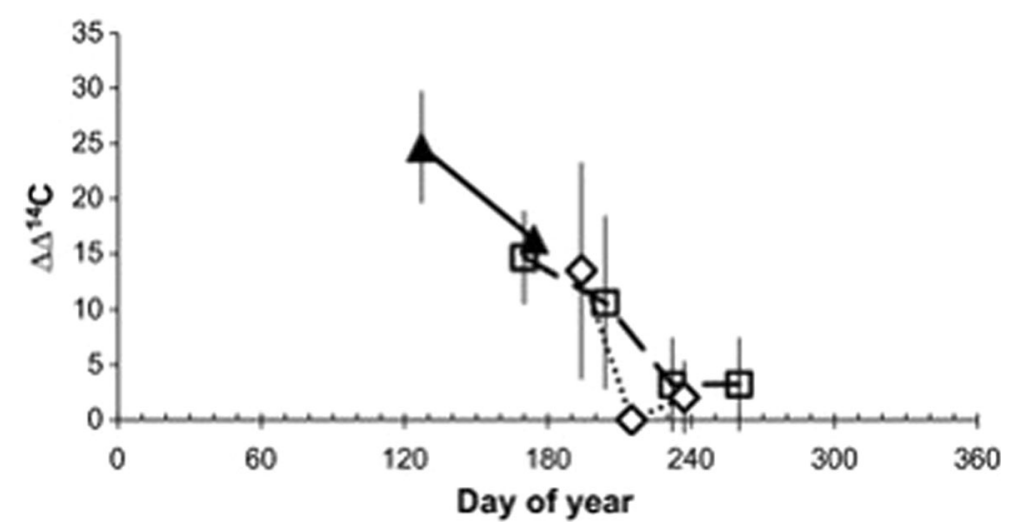

Fig. 6 Growing season patterns for the difference in $\Delta^{14} \mathrm{C}$ between root respiration and the atmosphere $\left(\Delta \Delta^{14} \mathrm{C}\right)$, which is used to infer $\mathrm{C}$ age, for three temperate Ameriflux forest sites. Howland forest (solid triangles), Harvard Forest deciduous site (open

carbohydrates stored by trees during the experiment continued to contribute to root respiration for at least two years after the isotopically distinct $\mathrm{CO}_{2}$ source was gone. Czimczik et al. (2006) found that as boreal forest stands matured following wildfire, root respiration tended to contain more stored C. Examining soil-respired ${ }^{14} \mathrm{CO}_{2}$ in a deciduous forest in Northern Wisconsin, Phillips et al. (2013) found evidence for gradual microbial transition from previous-year to current-year substrates over the course of a growing season. Fresh root exudates appeared to be a preferred microbial substrate. In an arctic tundra ecosystem, Hartley et al. (2012) also found evidence for seasonal microbial switching, but found that mid-summer plant activity stimulated microbial decomposition of older soil organic matter (i.e. positive priming).

Collectively, these studies suggest that $R_{S}$ should be represented by more than two sources, with both $\mathrm{R}_{\mathrm{A}}$ and $\mathrm{R}_{\mathrm{H}}$ containing varying levels of fresh photosynthetic products and stored $\mathrm{C}$ pools throughout the year (Hopkins et al. 2013; Phillips et al. 2013), and over timescales of ecological succession (Czimczik et al. 2006). Using conventional assumptions for partitioning $\mathrm{R}_{\mathrm{S}}$ with ${ }^{14} \mathrm{C}\left(\mathrm{R}_{\mathrm{H}}=\right.$ 'old' and $\mathrm{R}_{\mathrm{A}}=$ 'recent', Fig. 5a) could lead to overestimates of $\mathrm{R}_{\mathrm{H}}$ early in the growing season when root respiration utilizes older stored $\mathrm{C}$, and underestimates of $\mathrm{R}_{\mathrm{H}}$ late in the growing season, if microbes have switched to recent $C$ substrates.

Determination of $\mathrm{R}_{\mathrm{A}}$ and $\mathrm{R}_{\mathrm{H}}$ ages by combining physical partitioning and isotopic monitoring also provides observations to test models with more than two discreet C pools (e.g. Parton et al. 2010; Sierra et al. 2012). For instance, Fig. 5c represents hypothetical squares), and Harvard forest evergreen site (open diamonds). Error bars are the larger of the standard deviation of replicates of the propagated error of $\Delta \Delta^{14} \mathrm{C}$ calculations. Reprinted with permission from Hopkins et al. (2013)

contributions of five discreet soil carbon pools ranging in turnover time from less than one year to millennial timescales, and two plant $\mathrm{C}$ pools with annual and decadal turnover times, that could give rise to the $\mathrm{C}$ ages shown in Fig. 5b. Such large ranges in ages of forest soil and root $\mathrm{C}$ have been established by measurements of plant, litter, and soil $\Delta^{14} \mathrm{C}$ (Gaudinski et al. 2000; Trumbore 2000), and have been used to develop soil $\mathrm{C}$ models with excellent predictive power. For instance, Sierra et al. (2012) showed that $C$ turnover times inferred from plant, litter, and soil $\Delta^{14} \mathrm{C}$ measurements in 1996 were able to accurately predict gradual changes in $\Delta^{14} \mathrm{C}$ measured in $\mathrm{R}_{\mathrm{S}}$ over the following decade.

Figure 5 also demonstrates why the relationship between $R_{S}$ and soil $C$ stocks can be unclear to many, and why modelers have found it difficult to use bulk (unpartitioned) $\mathrm{R}_{\mathrm{S}}$ data to test soil $\mathrm{C}$ pool models. Currently, the most abundant and widely-used datasets used for soil C model testing do not include in situ $\mathrm{R}_{\mathrm{S}}$, but instead are from litter bag decay experiments (Bonan et al. 2013), laboratory incubations, soil C stock sizes, and ${ }^{14} \mathrm{C}$ ages of solid soil C (Jenkinson et al. 2008; Koven et al. 2013). Laboratory incubations and litter bag experiments have demonstrated that a large fraction of soil $\mathrm{C}$ turns over slowly, and solid soil ${ }^{14} \mathrm{C}$ data indicates the timescale of the slowest $\mathrm{C}$ pools can be on timescales of century to millennia (Trumbore 2009). But $R_{S}$ is dominated by relatively young $C$ that turns over in a year or less (Gaudinski et al. 2000), and that may contribute very little to the soil organic $\mathrm{C}$ pool. Collectively this suggests $R_{S}$ can vary substantially from year to year with little impact on soil carbon 
aggradation or decay (Sierra et al. 2012). It is impossible to know from bulk $R_{S}$ data, or even from estimated $R_{H}$, when a change in the contributions of long-lived 'old' soil $\mathrm{C}$ pools has taken place, unless age estimates of the fluxes can also be determined.

However, isotopic age estimates of $\mathrm{R}_{\mathrm{H}}$ can allow changes in SOC turnover to be detected years to decades before they would be measurable from sampling solid SOC (Gaudinski et al. 2000; Hartley et al. 2012). For instance, Sierra et al. (2012) provided compelling ${ }^{14} \mathrm{C}$ evidence that global change factors, including warming and $\mathrm{N}$-deposition, resulted in a transfer of $\mathrm{C}$ from longlived to rapid-turnover pools in soil experiments at Harvard Forest. Moving forward, it would be advantageous for more studies to combine ${ }^{14} \mathrm{C}$ or pulse-chase ${ }^{13} \mathrm{C}$ monitoring with physical partitioning approaches, to provide a baseline for detecting climate change impacts on organic matter decomposition. Furthermore, there is some urgency to apply ${ }^{14} \mathrm{C}$ measurements soon, given the anticipated loss of ${ }^{14} \mathrm{C}$ bomb-C determinations in coming decades (Graven 2015).

Opportunity: evaluate abiotic sources of soil $\mathrm{CO}_{2}$

There is also a relatively unexplored opportunity to utilize partitioning experiments to evaluate abiotic sources of soil $\mathrm{CO}_{2}$. The general assumption in most soil flux studies is that only biological communities near the soil surface are responsible for the observed $\mathrm{CO}_{2}$. This is of course a simplification, and $\mathrm{CO}_{2}$ in the soil profile may originate

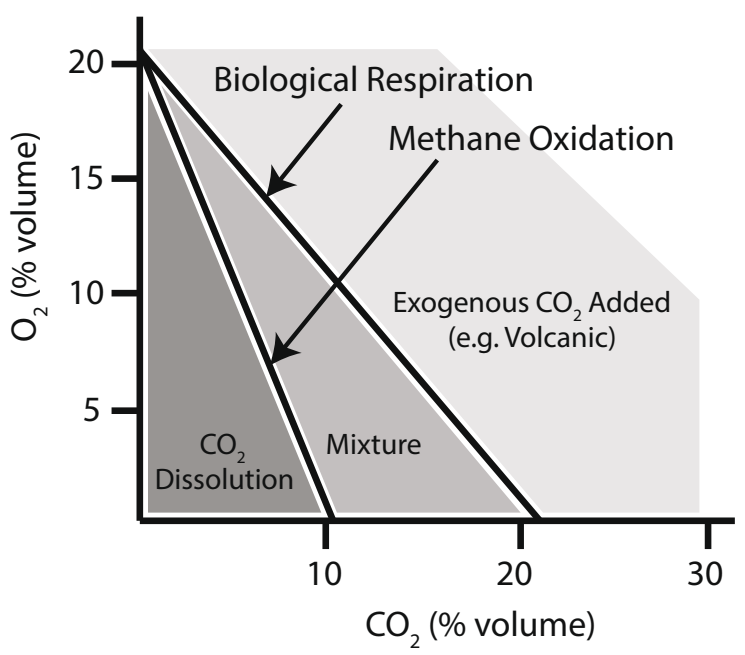

Fig. 7 Mixing lines for biological respiration and methane oxidation (left) and example data for different idealized environments, each with strong source dominance (right) except for oil and gas from a variety of sources, including soil pedogenic or liquid water carbonates (Cerling et al. 1991; SerranoOrtiz et al. 2010; Shanhun et al. 2012; Risk et al. 2013b), methane oxidation (Romanak et al. 2012; Mills et al. 2013), or volcanic activity (Werner and Brantley 2003; Viveiros et al. 2008; Beulig et al. 2016). Soil sinks for $\mathrm{CO}_{2}$ may also exist, for example from carbonate dissolution (Shanhun et al. 2012) and C-fixation by chemoautotrophic microbes (Beulig et al. 2016). Though these abiotic and anaerobic mechanisms are probably quite common and contribute at some scale to $\mathrm{R}_{\mathrm{S}}$, they are often studied only under specialty situations and we lack widespread estimates of the abiotic flux contribution. At individual sites, however, the contribution can be large: for instance, Rey et al. (2014) determined that volcanic $\mathrm{CO}_{2}$ emissions accounted for almost $50 \%$ of net ecosystem carbon balance at an arid steppe site in Spain.

Various noble gas tracers and isotopic methods are available for tracing $\mathrm{CO}_{2}$ origin (Wilkinson et al. 2010), but there are also simpler approaches for abiotic partitioning that can readily be integrated into existing study sites. Researchers can 1) increase their use of geochemistry and gas ratios, 2) mine continuous temporal records more effectively, and/or 3) add gradient sensors or measurements. For example, the ratios of two common gases can help infer source contributions based on known stoichiometric relationships (Fig. 7).

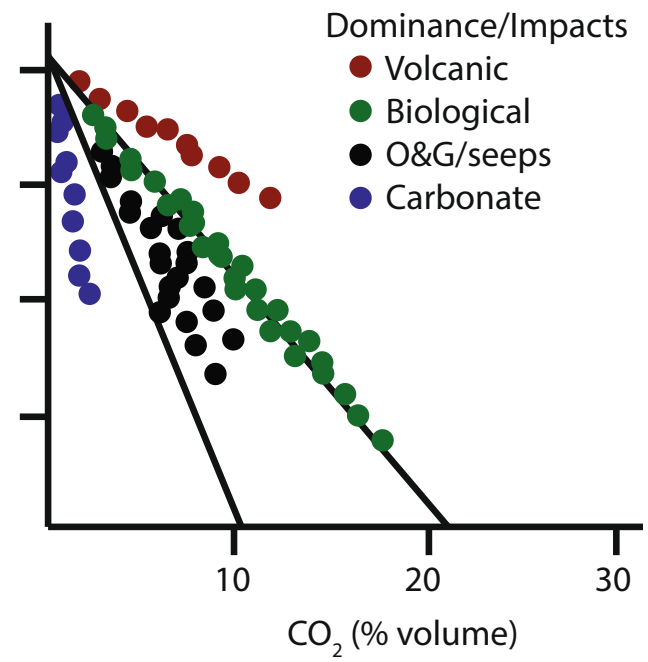

thermogenic seeps, which are shown here as being mixed with biological contributions. Modified from Romanak et al. (2012) 
What would a generic biotic-abiotic $\mathrm{R}_{\mathrm{S}}$ measurement system look like? It would measure $\mathrm{CO}_{2}$ plus another useful accessory such as $\mathrm{O}_{2}$, at the surface (flux), and potentially other gases at a limited number of depths (concentrations) along with in-situ diffusivity measurement. Because aerobic respiration involves a theoretically constant ratio of $\mathrm{CO}_{2}$ production to $\mathrm{O}_{2}$ consumption, measuring deviations from this ratio can allow quantification of anaerobic respiration, or wetting events that preferentially store or advect $\mathrm{CO}_{2}$ over $\mathrm{O}_{2}$ (Turcu et al. 2005; Angert et al. 2015). Oxygen sensors are widely available, and although high accuracy is required for this application, they could presumably be added to autochambers (Liptzin et al. 2011). The system would likely need to run as often as possible, both to avoid the problem of bias from sparse data (Creelman 2015), but also to capture periods when biotic activity is negligible, so that other interesting background processes (e.g. geologic seepage, carbonate dissolution, wind ventilation of soil $\mathrm{CO}_{2}$ ) are brought into focus.

Additionally, $\mathrm{R}_{\mathrm{S}}$ studies do not often make full use of spatiotemporal possibilities to evaluate abiotic drivers. Non-growing season data are particularly well suited for identifying the presence of continuous abiotic activity such as volcanic contributions that may otherwise be masked (Risk et al. 2013a; Rey et al. 2014). Also, with the growth of temporally rich data from autochamber systems, spectral or frequency-based analytical techniques (e.g., frequency filtering, wavelet) become useful (Vargas et al. 2010b; Heinemeyer et al. 2012). While not currently common, they may also help identify abiotic background drivers of $R_{S}$ that may vary on unusual timescales for biological processes (i.e., independently of moisture, temperature, and phenology). Finally, from a spatial perspective, subsurface concentration gradient studies can be extremely useful in helping identify layer-by-layer processes (Tang et al. 2003; Davidson et al. 2006; Vargas and Allen 2008; Phillips et al. 2012; Maier and Schack-Kirchner 2014), and basal fluxes that originate from below the soil profile. It would not be surprising if much of the new understanding in $R_{S}$ over the coming years comes from gradient-based techniques, because of its ability to vertically resolve respiration across gradients of soil age, substrate quality, and $\mathrm{O}_{2}$ concentration, and because of the potential for parameterizing physicalbiogeochemical models.

\section{Challenge 3: better upscaling and downscaling}

The final challenge we address is in how to bridge $R_{S}$ measurements to spatial and temporal scales matching those of other ecosystem $\mathrm{C}$ measurements and model outputs. One of the largest uncertainties associated with comparisons between $\mathrm{R}_{\mathrm{ECO}}$ and $\mathrm{R}_{\mathrm{S}}$ (Challenge 1 , above) is the upscaling of chamber measurements to the footprint of the EC tower. The difference in ground measurement areas between individual soil collars $\left(0.01-0.1 \mathrm{~m}^{2}\right)$ and a $30 \mathrm{~m}$ forest EC tower $\left(\sim 1 \mathrm{~km}^{2}\right)$ give a scaling factor of $10^{5}-10^{6}$. Similarly, gap-filling monthly survey measurements to infer an annual total requires estimating over $99 \%$ of the time period. These numbers suggest that high spatial variability of $R_{S}$ is an additional plausible reason that $R_{S}$ is often not matched well with $\mathrm{R}_{\mathrm{ECO}}$.

Upscaling often entails taking a simple mean of measurement locations distributed across a tower footprint, and some studies have performed power calculations to derive the minimum acceptable number of $\mathrm{R}_{\mathrm{S}}$ measurements (Rodeghiero and Cescatti 2008). More rarely, regression models relating $\mathrm{R}_{\mathrm{S}}$ to the spatial distribution of its main environmental drivers, including roots, microbial substrates, soil temperature and soil moisture, or soil depth (Tang and Baldocchi 2005; Saiz et al. 2006; Savage et al. 2008; Martin and Bolstad 2009), are used. Often, however, other easily measured soil variables have limited capability to predict spatial variation in $\mathrm{R}_{\mathrm{S}}$ (Stoyan et al. 2000; Allaire et al. 2012; Kreba et al. 2013). For instance, at Harvard Forest, Giasson et al. (2013) found no more correlation among neighboring collars than among distant collars. In fact, they showed that variation due to spatial variability was as great as the variation due to experimentally imposed manipulations, such as soil heating, rain exclusion, selective harvest, and $\mathrm{N}$ additions.

Multiple studies have discussed the challenge of representing spatial heterogeneity of $R_{S}$ (e.g. Stoyan et al. 2000) where geostatistical techniques have been used to demonstrate the challenge of measuring $\mathrm{R}_{\mathrm{S}}$ from the plot to the landscape scale (Kosugi et al. 2007; Teixeira et al. 2013). One of the reasons for this lack of predictive ability is the tendency of $R_{S}$ to have "hotspots" and "hot moments", locations or periods of time with disproportionally high $\mathrm{R}_{\mathrm{S}}$ emissions compared to surrounding conditions (Kim et al. 2012; Leon et al. 2014). (sensu McClain et al. 2003) suggested that these occur when episodic hydrologic flow paths 
deliver substrates and nutrients in abundance to locations of high biological activity. However, Leon et al. (2014) showed that hotspots may not be predictable, as they may appear in areas where no evidence of high metabolic activity was present during antecedent measurements. Furthermore, Leon et al. showed that the location and intensity of hot spots can change seasonally, and can be correlated with different environmental variables in different seasons (Fig. 8).

This spatial variability makes measuring $R_{S}$ representatively and robustly, and using these measurements to compare and evaluate $\mathrm{R}_{\mathrm{ECO}}$ derived from $\mathrm{EC}$, more challenging. One way researchers can help to identify the presence of hot spots and hot moments to other data users is to report the full probability distribution function (or at least the second and third moments - variance and skewness) of observed soil respiration in addition to site means (Lavoie et al. 2014). Ideally, complete data sets that include full time series of raw data and all sampling locations would be made available in archived repositories, allowing users to define hot spots and hot moments using different algorithms, and re-analyze older data as new techniques or insights become available.

Opportunity: 'smarter' quantification of site-level $R_{S}$

While we do not offer a blanket approach for upscaling, several techniques can provide better site- or ecosystemlevel estimates than simple means of chamber locations. If $\mathrm{R}_{\mathrm{S}}$ spatial variance and its drivers are well quantified, stratified (as opposed to random) sampling can allow for more efficient measurements and robust upscaling
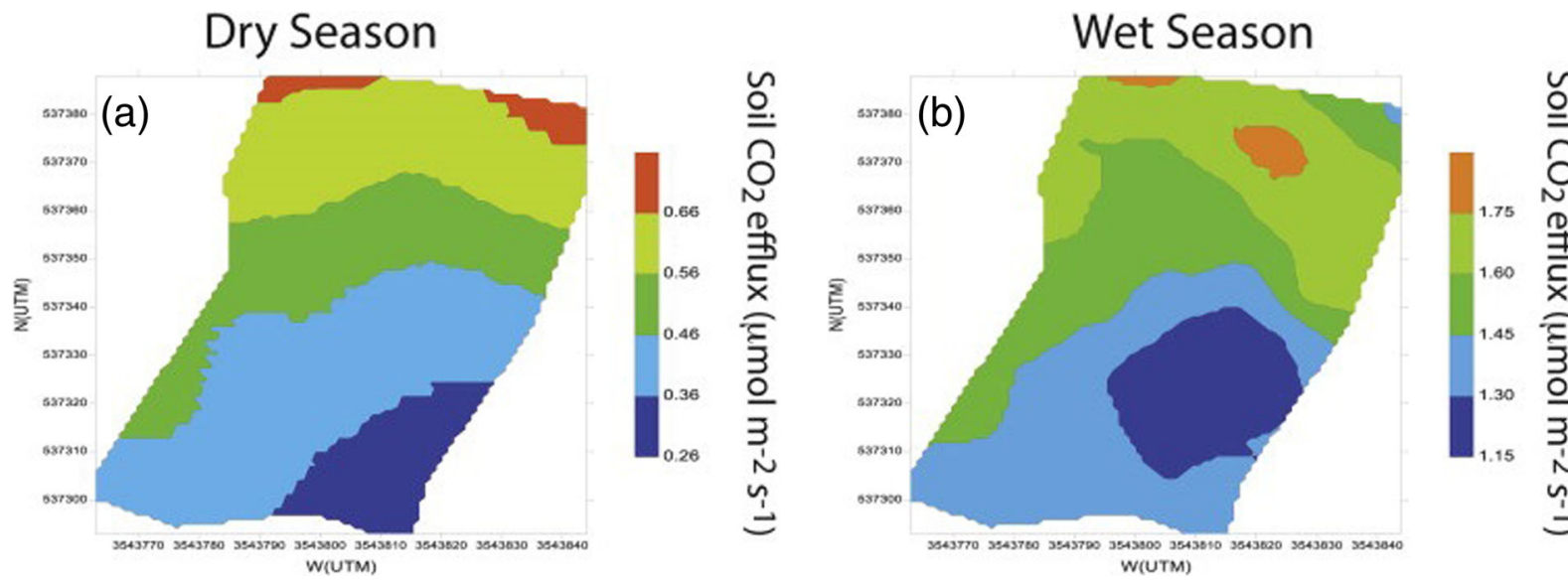

Fig. 8 Spatial patterns of $R_{S}$ generated by ordinary kriging for the dry season (a) and wet season (b) in a Mediterranean shrubland. The figure shows the emergence of a hot spot (i.e., area of high $\mathrm{R}_{\mathrm{S}}$ )
(Rodeghiero and Cescatti 2008). For instance, soil chambers in distinct vegetation types can be weighted by the fractional extent of vegetation types within the EC tower footprint (Giasson et al. 2013). Taking this approach a step further, footprint analysis can be employed to account for movement of the EC tower footprint through time, i.e. applying a time-varying source weight function to individual chambers (Budishchev et al. 2014). In addition, random variability of $R_{S}$ across space and scales can be simulated with geostatistical techniques such as kriging (Herbst et al. 2012; Allaire et al. 2012; Leon et al. 2014).

In complex terrain, in contrast to typically flat EC sites, empirical models relating $\mathrm{R}_{\mathrm{S}}$ to hydrologic factors may provide 'smart' upscaling to watershed scales. For instance, Riveros-Iregui and McGlynn (2009) demonstrated that upland accumulated area was a robust predictor of $R_{S}$, because both soil moisture and $R_{S}$ increased at valley bottoms relative to ridges. However, the opposite pattern was found at a different Western U.S. site, where elevation-related cooling increased soil moisture, and thus $\mathrm{R}_{\mathrm{S}}$, at high elevation positions (Berryman et al. 2015). Ultimately, researchers must discern effects that covary with topography such as soil moisture, soil organic carbon (as available substrate for Rs), temperature, and vegetation type to fully understand the biophysical controls on $R_{S}$ in complex terrain.

$R_{S}$ measurements frequently must be scaled in time as well as space, as most site-level estimates are derived from sporadic manual measurements, not continuous ones. While seasonal differences in $\mathrm{R}_{\mathrm{S}}$ can be large (e.g. Khomik et al. 2006), seasonal patterns tend to be

during the wet season (orange area in panel b). Reprinted with permission from Leon et al. (2014) 
relatively straightforward to account for in gap-filling regression models, absent the effects of disturbances or drought (Borken et al. 2006; Martin et al. 2012; Barba et al. 2016). More difficult to simulate are $R_{S}$ 'bursts' after rewetting or thawing (Kim et al. 2012). This phenomenon, known as the "Birch effect", is thought to be due to some combination of increased microbial populations, higher metabolism, and changes in the physical protection and hydrological connectivity of the soil (Xu and Baldocchi 2004; Tang and Baldocchi 2005; Oikawa et al. 2014). These bursts present similar challenges as other types of 'hot moments', but have more predictable occurrence, and in some cases can constitute an appreciable fraction of annual fluxes. Also difficult to represent are seasonal or diurnal hysteresis of $\mathrm{R}_{\mathrm{S}}$ responses to temperature (Kicklighter et al. 1994; Riveros-Iregui et al. 2007; Phillips et al. 2011), and linkages and lags between photosynthesis and respiration (reviewed by Carbone and Vargas 2007; Davidson and Holbrook 2009). Oikawa et al. (2014) proposed a model that could simulate wetting-related pulses and temperature hysteresis, and Zhang et al. (2015)used a $\mathrm{CO}_{2}$ gas transport model to simulate temperature hysteresis. However, there are presently no standardized gap-filling algorithms or approaches for soil respiration, unlike for EC (Moffat et al. 2007). In the most comprehensive work to date, Gomez-Casanovas et al. (2013) assessed a variety of gap-filling $\mathrm{R}_{\mathrm{S}}$ algorithms and found that different methods exhibited different levels of skill with data gaps of various lengths, but rarely produced large systematic biases. Obviously, continuous data are preferable to periodic campaign-style measurements for constructing annual carbon budgets, and systematic biases can be introduced when measurements are made always at the same time of day (Savage et al. 2008; Savage et al. 2009; Gomez-Casanovas et al. 2013). Nevertheless, supplemental periodic measurements with a portable instrument are generally necessary to capture site spatial variability.

In addition to estimating a site average $\mathrm{R}_{\mathrm{S}}$ it is necessary to estimate the associated uncertainty (Reichstein and Beer 2008). While uncertainty of individual $R_{S}$ chambers can be quantified readily (Pumpanen et al. 2004), describing site-level uncertainty is more difficult, as it includes uncertainty due to spatial variability in $R_{S}$, gap-filling assumptions, and the goodness of fit of the statistical model used for scaling (Lavoie et al. 2014). A growing body of research is indicating consistencies in the statistical features of $R_{S}$ in both time and space, work that may provide simplifying solutions for uncertainty quantification. For example, at Willow Creek Ameriflux site (Lavoie et al. 2014), at Harvard Forest (Savage et al. 2008), and at multiple sites around the world (Cueva et al. 2015), the standard deviation of $\mathrm{R}_{\mathrm{S}}$ measured at multiple locations within the ecosystems was heteroschedastic, increasing linearly with site average $\mathrm{R}_{\mathrm{S}}$. Similarly, in the temporal domain, the random error of $R_{S}$ (defined as the deviation between measures made at one location under assimilar-as-possible conditions) was found not only to scale with $R_{S}$, but to scale with the same slope across a large number of sites, and even in different ecosystems (Savage et al. 2008; Lavoie et al. 2014; Cueva et al. 2015).

Opportunity: downscaling tower measurements

In addition to scaling up $\mathrm{R}_{\mathrm{S}}$ to the $\mathrm{EC}$ site level, there are emerging opportunities for decomposing EC fluxes to capture spatial variability within the tower footprint, perhaps more in line with the spatial scale of $R_{S}$. Flux tower based $\mathrm{R}_{\mathrm{ECO}}$ estimates may suffer from systematic bias due to constantly changing flux footprint source area with time, as a function of wind direction, surface structural properties, and atmospheric stability (Schmid, 2002). However, techniques that take advantage of this footprint variability can be used to map spatial variation and provide gridded estimates of $\mathrm{R}_{\mathrm{ECO}}$.

The Environmental Response Function (ERF) approach (Metzger et al. 2013) is one such approach to direct attribute the measured flux to the actual source area of contribution and use that information to appropriately scale tower fluxes to other measurements such as chambers . As applied to towers (Xu et al. 2017), the ERF techniques estimates minute-to-minute variations in the flux footprint to compare measured fluxes against covarying spatial and temporal drivers. The comparison allows a statistical model to be built to map fluxes and their uncertainty across space, using a machine learning approach. With ERF, down-scaled NEE observations can then used to derive a re-upscaled, gridded $\mathrm{R}_{\mathrm{ECO}}$ and directly compared to point-level Rs chamber measurements. To date, ERF has only been applied to direct fluxes (NEE), but a new opportunity arises to use ERF in partitioning and improving comparison of daytime $\mathrm{R}_{\mathrm{ECO}}$ estimates and $\mathrm{R}_{\mathrm{S}}$. 


\section{Using $\mathbf{R}_{\mathrm{S}}$ for model development}

Aside from the impetus to use as many data sources as possible for data-model synthesis, field $\mathrm{R}_{\mathrm{S}}$ data have the tantalizing potential to provide a critical bridge across scales and domains. In $\mathrm{R}_{\mathrm{H}}$ models, there is a significant scale gap between lab incubations and litter decomposition experiments, and the field- and global-scale questions that are being asked of these models. $R_{S}$ measurements scaled to site and ecosystem levels (see Challenge 3) could reduce some of this gap and bridge key spatialtemporal heterogeneities in the $\mathrm{R}_{\mathrm{H}}$ model. In addition, NEE is currently the only measurement routinely used for model development which crosses both soil and plant domains. Having additional information from $R_{S}$ for model benchmarking would allow modelers to better identify poorly-performing sections of land carbon models (Luo et al. 2012).

The few studies that have directly tested the value of $\mathrm{R}_{\mathrm{S}}$ for model fidelity also suggest the importance of these data. Keenan et al. (2013) rated the utility of data streams for data-model synthesis, and found $R_{S}$ data were one of the most valuable measurements for reducing uncertainty of forest productivity estimates. They concluded that most model improvement is seen with a limited number of measurement types, and speculated that the most valuable measurements provide information about turnover of $\mathrm{C}$ pools at both fast and very long timescales. Similarly, Zobitz et al. (2008) tested whether $R_{S}$ could be simulated by a forest $\mathrm{C}$ model using only NEE and soil $\mathrm{C}$ stock data for parameterization, and found that the model could not be satisfactorily constrained, implying that Rs brings distinct and unique information to any model-data assimilation exercise.

We see three types of model improvement activities that could utilize $\mathrm{R}_{\mathrm{S}}$ data: (1) data-model synthesis where the aim is reducing uncertainty of parameter estimates, (2) preventing models from predicting biologically implausible states, and (3) benchmarking a range of models to common sets of observations (Kelley et al. 2013). In Table 2 and below we give examples using $\mathrm{R}_{\mathrm{S}}$ data for each of these.

Data-model synthesis techniques attempt to identify and select models, parameters, and uncertainty that are more parsimonious or consistent with the entire range of collected observations. These approaches, which can be Bayesian in nature, attempt to propagate a probabilistic set of consistent parameters forward, allowing for direct estimation and partitioning of sources of uncertainty (LeBauer et al. 2013; Dietze et al. 2013). One advantage of these approaches is that simple assumptions often

Table 2 Uses of $\mathrm{R}_{\mathrm{S}}$ data for terrestrial model improvement

\begin{tabular}{|c|c|c|c|}
\hline Activity & Objective & Approach & References \\
\hline \multirow[t]{2}{*}{ Data Assimilation } & Improve NEE data reliability & $\begin{array}{l}\text { Reduce weight for data where } \mathrm{R}_{\mathrm{S}}>\text { Night } \\
\text { NEE. Assimilate upscaled, chamber- } \\
\text { based } \mathrm{R}_{\mathrm{ECO}} \text { estimates when available. }\end{array}$ & Speckman et al. (2015) \\
\hline & $\begin{array}{l}\text { Improve parameterization } \\
\text { of } R_{A} \text { and } R_{H}\end{array}$ & $\begin{array}{l}\text { Include } \mathrm{R}_{\mathrm{S}} \text { and other plant and soil } \mathrm{C} \\
\text { measures as joint constraints. }\end{array}$ & Keenan et al. (2013) \\
\hline \multirow{3}{*}{$\begin{array}{l}\text { Prevent model from } \\
\text { predicting biologically } \\
\text { implausible states }\end{array}$} & $\begin{array}{l}\text { Improve parameterization } \\
\text { of } \mathrm{R}_{\mathrm{A}}\end{array}$ & $\begin{array}{l}\text { Evaluate model against plant biometric } \\
\text { measures and } \mathrm{R}_{\mathrm{S}} \text { as co-constraints }\end{array}$ & Bloom and Williams 2015 \\
\hline & Simulate plant allocation & $\begin{array}{l}\text { Evaluate model against speed-of-link } \\
\text { between photosynthesis and } R_{S} \text {. }\end{array}$ & (Vargas et al. 2011a) \\
\hline & Simulate SOC turnover & $\begin{array}{l}\text { Evaluate } S O C \text { stock size and } R_{S} \text { as joint } \\
\text { constraints }\end{array}$ & $\begin{array}{l}\text { Bloom and Williams } \\
\text { 2015; Zobitz et al. } \\
\text { 2008; Richardson et al. } \\
\text { (2010); Keenan et al. } \\
\text { (2013) }\end{array}$ \\
\hline \multirow[t]{3}{*}{ Benchmark Analysis } & Evaluate $\mathrm{C}$ residence time & $\begin{array}{l}\text { Evaluate NPP or NEP (C inputs) with } \mathrm{R}_{\mathrm{S}}(\mathrm{C} \\
\text { outputs) as joint constraints }\end{array}$ & Luo et al. (2012) \\
\hline & & $\begin{array}{l}\text { Use in combination with } \mathrm{C} \text { stock data to } \\
\text { span short to long timescales. }\end{array}$ & Luo et al. (2012) \\
\hline & Evaluate seasonality & $\begin{array}{l}\text { Evaluate modeled patterns of } R_{H}, R_{A} \text {, or } \\
\text { their combination against } R_{S} \text {. }\end{array}$ & $\begin{array}{l}\text { Luo et al. (2012), Fig. 9, } \\
\text { this paper. }\end{array}$ \\
\hline
\end{tabular}


made on scaling, gap-filling, and single variable regression can be removed if model processes are able to simulate components or model outputs can be "sampled" like the original observation. For $\mathrm{R}_{\mathrm{S}}$, this means that infrequent survey measurements can be assimilated without requiring separate gap-filling procedures.

Particularly relevant for $\mathrm{R}_{\mathrm{S}}$, data-model synthesis allows observations to be used even when they do not match one-to-one with modeled variables. For instance, incorporating $\mathrm{R}_{\mathrm{S}}$ in data-model syntheses with a forest $\mathrm{C}$ model was found in one instance to improve estimation of NEE (Keenan et al. 2013), and in another instance to reduce the uncertainty in heterotrophic respiration and the size of soil carbon pools (Keenan et al. 2012). Direct model-data integration would require terrestrial $\mathrm{C}$ models to simulate belowground $\mathrm{R}_{\mathrm{A}}$, which many do not. Autotrophic respiration is usually split into growth and maintenance respiration processes, but rarely into separate above- and below-ground components (Medvigy et al. 2009; Oleson et al. 2010; Parton et al. 2010; Dunne et al. 2012). Pushing for the development of allocation schemes that distinguish belowground $\mathrm{R}_{\mathrm{A}}$ in global scale models would provide an elegant solution to the comparison problem, but it is by no means the only option.

In addition to reducing parameter uncertainty, another approach for data-model synthesis is to focus on preventing parameters and states that are not biologically plausible (Bloom and Williams 2015). A common problem for $\mathrm{C}$ models is equifinality: they can produce similar annual fluxes with different underlying parameters and process representations. Poor model parameterization is likely to translate to weak predictive power under changing environmental conditions. Perhaps the most powerful use of $R_{S}$ data is as a diagnostic tool to identify implausible parameterization of $R_{H}$ or $\mathrm{R}_{\mathrm{A}}$, as a form of ecological dynamic constraint (Bloom and Williams 2015). For instance, to check on the parameterization of $R_{A}$, one could use $R_{S}$ as a co-constraint with aboveground measures of plant growth, such as biometric or remotely-sensed measures of NPP. To check on the parameterization of $\mathrm{R}_{\mathrm{H}}$, one could use $\mathrm{R}_{\mathrm{S}}$ and a co-constraint with $\mathrm{C}$ stock or ${ }^{14} \mathrm{C}$ data, thereby encompassing turnover processes at immediate to long timescales.

Comparing modeled and observed seasonal dynamics of $\mathrm{R}_{\mathrm{S}}$ provides another means for bounding plausible conditions. There are some situations (e.g. winter dormancy) where $\mathrm{R}_{\mathrm{A}}$ is all but shut down and we would expect $R_{S}$ to be roughly equal to $R_{H}$. In these cases, relatively straightforward direct comparison of $\mathrm{R}_{\mathrm{S}}$ and $\mathrm{R}_{\mathrm{H}}$ is likely reasonable. More creative comparisons could be done by examining relative shifts of $R_{S}$ across an environmental gradient where either variations in $R_{H}$ or $R_{A}$ are expected to dominate, or where belowground $R_{A}$ is expected to be proportional to some other measurement like leaf $\mathrm{R}_{\mathrm{A}}$. Ideally competing hypothesis would be codified in model formulations, leading itself to formal data-model integration and model selections. Clearly, this is a study-specific approach that requires a deep understanding of the mechanisms being investigated, but has the potential to stimulate creative uses of data-model synthesis techniques.

Building on these ideas, $\mathrm{R}_{\mathrm{S}}$ data can also play a valuable role in benchmarking multiple models against common sets of observations. Luo et al. (2012) summarized several key qualities that benchmark data should have. First, benchmark data should reflect properties that are fundamental to all ecosystems, such as $\mathrm{C}$ uptake and residence time. As discussed above (see section 2.3), $\mathrm{R}_{\mathrm{S}}$ provides a critical data source for evaluating both soil and plant $\mathrm{C}$ residence time. It is particularly powerful for evaluating residence time at the timescale of manipulative experiments, and when measured in combination with isotopic dating methods. Second, benchmark data should be selected to reduce equifinality. $R_{S}$ provides a focus on soil processes that may be obscured in EC data or remotely-sensed data products, and is thus particularly useful for detecting weaknesses in belowground parameterization. $\mathrm{R}_{\mathrm{S}}$ data are also abundant and geographically widespread, another important quality for reducing equifinality in global-scale models. Third, benchmark data should be reliable. As discussed above (Challenge 1), $R_{S}$ measurement systems have the benefit of validation under laboratory conditions, and are likely more reliable than EC-derived estimates of $\mathrm{R}_{\mathrm{ECO}}$.

Luo et al. (2012) also noted that land models can be evaluated on the basis of seasonal patterns rather than absolute values. $\mathrm{R}_{\mathrm{S}}$ data are particularly useful for calibrating soil models at seasonal timescales, since soil C stock and even litterbag data integrate decomposition processes occurring over timescales $\geq 1$ year. For example, Fig. 9 shows seasonal patterns in $R_{H}$ and $\mathrm{R}_{\mathrm{ECO}}$ simulated by the Community Land Model (CLMv.4.0) in comparison to observed $\mathrm{R}_{\mathrm{S}}$ and $\mathrm{R}_{\mathrm{ECO}}$ from the a pine forest site in Oregon (US-ME2, model 


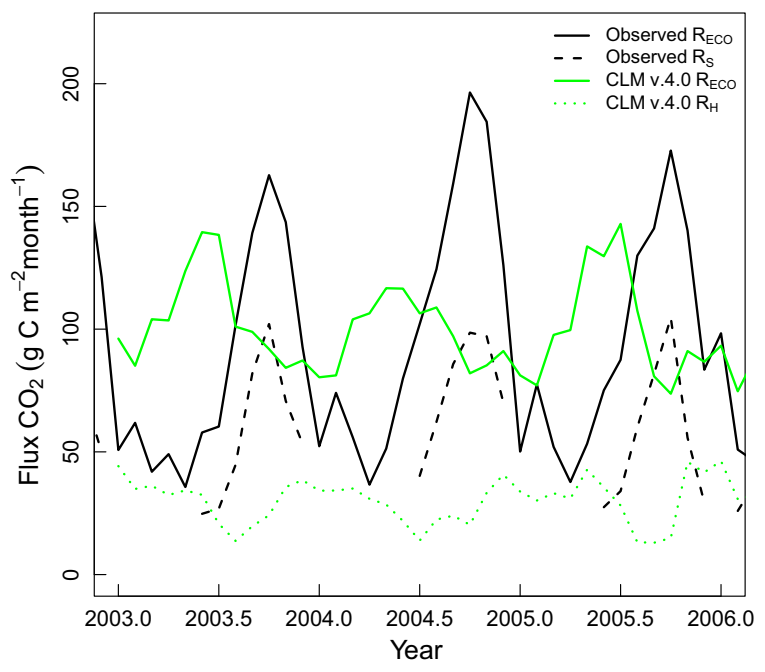

Fig. 9 A comparison of $\mathrm{R}_{\mathrm{H}}$ and $\mathrm{R}_{\mathrm{ECO}}$ modeled with CLM v.4.0 to chamber $\mathrm{R}_{\mathrm{S}}$ and EC-based $\mathrm{R}_{\mathrm{ECO}}$ (Level 4 data) at the AmeriFlux Metolius intermediate pine site (US-ME2). Modeled $\mathrm{R}_{\mathrm{ECO}}$ peaked two to three months earlier than observations, missed a large portion of the growing season, and is decoupled from $\mathrm{R}_{\mathrm{H}}$, which peaked in winter rather than during the growing season. Model output is from Hudiburg et al. (2013)

data from Hudiburg et al. 2013). Even after site-specific tuning of the model, seasonal patterns had considerable mismatch with observations. Modeled fluxes were strongly suppressed by seasonal summer drought. As a result, $R_{H}$ peaked in winter rather than during the growing season, and modeled $\mathrm{R}_{\mathrm{ECO}}$ peaked two to three months early, demonstrating fundamental problems in representation of soil and plant activity.

\section{Conclusions and future directions}

$R_{S}$ data are a rich source of information on soil responses to land use and climate factors, and are important for advancing our understanding of the terrestrial $\mathrm{C}$ cycle. However, to a large extent $R_{S}$ data have not been integrated with modeling efforts nor with analyses of related C fluxes and pools. We argue that in field studies, $\mathrm{R}_{\mathrm{S}}$ data are particularly useful for:

1) Identifying and potentially gap-filling low-quality nighttime $E C$ data. $\mathrm{R}_{\mathrm{S}}$ data are completely independent of, and not subject to the same nighttime biases as EC. They therefore provide a lower plausible bound for $\mathrm{R}_{\mathrm{ECO}}$ and more generally an additional EC data quality metric. $\mathrm{R}_{\mathrm{S}}$ measures can also be independently validated such as with sand-column flux generators. For these reasons, $\mathrm{R}_{\mathrm{S}}$ measurements should be considered important components of EC site instrument arrays, particularly at forest sites with complex canopies.

2) Determining soil responses to non-equilibrium conditions over experimental time frames. Given the slow turnover of the majority of soil $\mathrm{C}$ pools and high spatial variability, it is often difficult to detect statistically significant changes in soil $\mathrm{C}$ stocks in response to manipulations of land use or climate variables. Measurements of $R_{S}$ and partitioned $\mathrm{R}_{\mathrm{H}}$ components therefore provide an important means to detect experimental treatment effects on soil $\mathrm{C}$ turnover.

3) Identifying sources of $R_{S}$. While partitioning $R_{S}$ into autotrophic and heterotrophic components is valuable in its own right, applying physical partitioning in combination with isotopic monitoring makes it possible to evaluate contributions from recent and old $\mathrm{C}$ by both plants and microbes, as well as abiotic $\mathrm{CO}_{2}$ sources, under field conditions.

4) Quantifying spatial variability within tower footprints. Soil flux measurements can be used to identify hot spots and hot moments, evaluate spatial variables that control $R_{S}$, and also evaluate the representativeness of EC tower measurements within the larger domain.

In addition, $\mathrm{R}_{\mathrm{S}}$ data can be used in the following ways to improve terrestrial $\mathrm{C}$ cycle models:

1) Improving data reliability. $\mathrm{R}_{\mathrm{S}}$ provide directlymeasured respiration fluxes, in contrast to inferred EC fluxes based on partitioning NEP, and can be used to reduce the weight given to low quality EC data during data assimilation procedures.

2) Testing multiple-pool soil $C$ models. When measured in combination with partitioned fluxes $\left(\mathrm{R}_{\mathrm{H}}\right.$ and $\mathrm{R}_{\mathrm{A}}$ ), or ${ }^{14} \mathrm{C}$ abundance, $\mathrm{R}_{\mathrm{S}}$ data can be utilized for calibration of complex soil $\mathrm{C}$ models that represent 'new' and 'old' $\mathrm{C}$ contributions to both $\mathrm{R}_{\mathrm{H}}$ and $\mathrm{R}_{\mathrm{A}}$, or additional $\mathrm{C}$ sources, such as from geologic sources.

3) Preventing biologically implausible states. When used as a joint constraint with soil $\mathrm{C}$ stock data, $\mathrm{R}_{\mathrm{S}}$ can improve modeled soil $\mathrm{C}$ turnover across immediate to very long timescales. When used as a joint constraint with plant growth data, $R_{S}$ can provide a plausibility test for evaluating $\mathrm{R}_{\mathrm{A}}$ and plant allocation. 
4) Addressing model equifinality. $R_{S}$ data can help to ensure that belowground processes are wellconstrained in complex terrestrial models. Because $\mathrm{R}_{\mathrm{S}}$ crosses scales and plant and soil domains, it can reduce the uncertainty of several related variables in data-model synthesis techniques, including NEE, $\mathrm{R}_{\mathrm{A}}$, and $\mathrm{R}_{\mathrm{H}}$, and soil $\mathrm{C}$ stocks.

5) Providing data for model benchmarking. Because $\mathrm{R}_{\mathrm{S}}$ data are abundant, geographically widespread, and generally reliable, they have qualities that make them well-suited for benchmarking models.

Taking advantage of the full potential of $\mathrm{R}_{\mathrm{S}}$ measurements will require a concerted effort to make $R_{S}$ data more accessible and intercomparable among sites. Many measurement 'best practices' and data processing $\mathrm{QA} / \mathrm{QC}$ procedures have been suggested, but need to be more broadly adopted by the terrestrial ecology community (Bahn et al. 2008; Heinemeyer et al. 2011; Gomez-Casanovas et al. 2013; Lavoie et al. 2014; Maier and Schack-Kirchner 2014; Cueva et al. 2015). While the Global Soil Respiration Database (Bond-Lamberty and Thomson 2010) has made an extensive amount of seasonally and annually averaged Rs data available, similar efforts are needed to gather and make publicly available instantaneous flux measurements from survey campaigns and autochambers (McFarlane et al. 2014). Ideally, efforts to catalog both raw and processed $\mathrm{R}_{\mathrm{S}}$ data would allow comparison with contemporaneous EC tower fluxes and other soil C data, including SOC stocks, isotopes measurements, and related biogeochemistry data. These efforts can help to usher new global syntheses, and progress in both measurement and modeling realms.

\footnotetext{
Acknowledgments ARD acknowledges support to UW from NSF Advances in Biological Informatics awards \#1062204 and \#1457897. Funding for AmeriFlux data resources was provided by the U.S. Department of Energy's Office of Science. RV acknowledges support from US Department of Agriculture awards \# 201302758 and \# 2014-67003-22070. BBL was supported by the Office of Science of the U.S. Department of Energy as part of the Terrestrial Ecosystem Sciences Program. KTB was supported by the Linus Pauling Distinguished Postdoctoral Fellowship program, part of the Laboratory Directed Research and Development Program at Pacific Northwest National Laboratory, a multiprogram national laboratory operated by Battelle for the U.S. Department of Energy. JT was supported by the National Science Foundation grants PLR-1417763, DBI-959333, and AGS-1005663 and the University of Chicago and the MBL Lillie Research Innovation Award.
}

\section{References}

Alekseychik P, Mammarella I, Launiainen S et al (2013) Evolution of the nocturnal decoupled layer in a pine forest canopy. Agric For Meteorol 174-175:15-27. doi:10.1016/j.agrformet.2013.01.011

Allaire SE, Lange SF, Lafond JA et al (2012) Multiscale spatial variability of $\mathrm{CO} 2$ emissions and correlations with physicochemical soil properties. Geoderma 170:251-260. doi:10.1016/ j.geoderma.2011.11.019

Anav A, Friedlingstein P, Kidston M et al (2013) Evaluating the Land and Ocean Components of the Global Carbon Cycle in the CMIP5 Earth System Models. J Clim 26:6801-6843. doi:10.1175/JCLI-D-12-00417.1

Angert A, Yakir D, Rodeghiero $\mathrm{M}$ et al (2015) Using $\mathrm{O}_{2}$ to study the relationships between soil $\mathrm{CO}_{2}$ efflux and soil respiration. Biogeosciences 12:2089-2099. doi:10.5194/bg-12-20892015

Aubinet M, Feigenwinter C (2010) Direct CO2 advection measurements and the night flux problem. Agric For Meteorol 150:651-654. doi:10.1016/j.agrformet.2010.03.007

Aubinet M, Heinesch B, Yernaux M (2003) Bound-Layer Meteorol 108(3):397-417. doi:10.1023/A:1024168428135

Aubinet M, Feigenwinter C, Heinesch B et al (2012) Nighttime Flux Correction. In: Aubinet M, Vesala T, Papale D (eds) Eddy Covariance. Springer Netherlands, Dordrecht, pp. 133-157

Bahn M, Rodeghiero M, Anderson-Dunn M et al (2008) Soil Respiration in European Grasslands in Relation to Climate and Assimilate Supply. Ecosystems 11:1352-1367. doi:10.1007/s10021-008-9198-0

Bahn M, Schmitt M, Siegwolf R et al (2009) Does photosynthesis affect grassland soil-respired $\mathrm{CO}_{2}$ and its carbon isotope composition on a diurnal timescale? New Phytol 182:451460. doi:10.1111/j.1469-8137.2008.02755.x

Bahn M, Reichstein M, Davidson EA et al (2010) Soil respiration at mean annual temperature predicts annual total across vegetation types and biomes. Biogeosciences 7:2147-2157. doi:10.5194/bg-7-2147-2010

Bain WG, Hutyra L, Patterson DC, Bright AV, Daube BC, William Munger J, Wofsy SC (2005) Wind-induced error in the measurement of soil respiration using closed dynamic chambers. Agric For Meteorol 131(3-4):225-232. doi:10.1016/j. agrformet.2005.06.004

Baker IT, Prihodko L, Denning AS et al (2008) Seasonal drought stress in the Amazon: Reconciling models and observations. J Geophys Res Biogeosciences 113. doi:10.1029/2007 JG000644

Barba J, Curiel Yuste J, Poyatos R et al (2016) Strong resilience of soil respiration components to drought-induced die-off resulting in forest secondary succession. Oecologia. doi:10.1007/s00442-016-3567-8

Barr AG, Morgenstern K, Black TA et al (2006) Surface energy balance closure by the eddy-covariance method above three boreal forest stands and implications for the measurement of the $\mathrm{CO} 2$ flux. Agric For Meteorol 140:322-337. doi:10.1016/j.agrformet.2006.08.007

Berryman EM, Barnard HR, Adams HR et al (2015) Complex terrain alters temperature and moisture limitations of forest soil respiration across a semiarid to subalpine gradient: 
rocky mountain forest soil respiration. J Geophys Res Biogeosciences 120:707-723. doi:10.1002/2014JG002802

Beulig F, Urich T, Nowak M et al (2016) Altered carbon turnover processes and microbiomes in soils under longterm extremely high $\mathrm{CO} 2$ exposure. Nat Microbiol 1: 15025. doi:10.1038/nmicrobiol.2015.25

Bloom AA, Williams M (2015) Constraining ecosystem carbon dynamics in a data-limited world: integrating ecological "common sense" in a model-data fusion framework. Biogeosciences 12:1299-1315. doi:10.5194/bg-12-12992015

Bolstad PV, Davis KJ, Martin J, Cook BD, Wang W (2004) Component and whole-system respiration fluxes in northern deciduous forests. Tree Physiol 24(5):493-504

Bonan GB, Hartman MD, Parton WJ, Wieder WR (2013) Evaluating litter decomposition in earth system models with long-term litterbag experiments: an example using the Community Land Model version 4 (CLM4). Glob Change Biol 19:957-974. doi:10.1111/gcb.12031

Bond-Lamberty B, Thomson A (2010) A global database of soil respiration data. Biogeosciences 7:1915-1926. doi:10.5194/ bg-7-1915-2010

Bond-Lamberty B, Wang C, Gower ST (2004) A global relationship between the heterotrophic and autotrophic components of soil respiration? Glob Change Biol 10:1756-1766. doi:10.1111/j.1365-2486.2004.00816.x

Boone RD, Nadelhoffer KJ, Canary JD, Kaye JP (1998) Roots exert a strong influence on the temperature sensitivityof soil respiration. Nature 396(6711):570-572

Borken W, Savage K, Davidson EA, Trumbore SE (2006) Effects of experimental drought on soil respiration and radiocarbon efflux from a temperate forest soil. Glob Change Biol 12:177-193. doi:10.1111/j.1365-2486.2005. 001058.x

Braswell BH, Sacks WJ, Linder E, Schimel DS (2005) Estimating diurnal to annual ecosystem parameters by synthesis of a carbon flux model with eddy covariance net ecosystem exchange observations. Glob Change Biol 11:335-355. doi:10.1111/j.1365-2486.2005.00897.x

Budishchev A, Mi Y, van Huissteden J et al (2014) Evaluation of a plot-scale methane emission model using eddy covariance observations and footprint modelling. Biogeosciences 11: 4651-4664. doi:10.5194/bg-11-4651-2014

Carbone MS, Vargas R (2007) Automated soil respiration measurements: new information, opportunities and challenges. New Phytol 177:295-297. doi:10.1111/j.14698137.2007.02328.x

Carbone MS, Czimczik CI, McDuffee KE, Trumbore SE (2007) Allocation and residence time of photosynthetic products in a boreal forest using a low-level ${ }^{14} \mathrm{C}$ pulse-chase labeling technique. Glob Change Biol 13:466-477. doi:10.1111/j.13652486.2006.01300.x

Carey JC, Tang JY, Templer PH et al (2016) Temperature response of soil respiration is largely unaltered with experimental warming. PNAS. doi: 10.1073/pnas. 1605365113

Carvalhais N, Forkel M, Khomik M et al (2014) Global covariation of carbon turnover times with climate in terrestrial ecosystems. Nature. doi:10.1038/nature13731

Cerling TE, Solomon DK, Quade J, Bowman JR (1991) On the isotopic composition of carbon in soil carbon dioxide.
Geochim Cosmochim Acta 55:3403-3405. doi:10.1016/ 0016-7037(91)90498-T

Chen B, Coops NC, Dongjie F, Margolis HA, Amiro BD, Barr AG, Andrew Black T, Altaf Arain M, Bourque CP-A, Flanagan LB, Lafleur PM, Harry McCaughey J, Wofsy SC (2011) Assessing eddy-covariance flux tower location bias across the Fluxnet-Canada Research Network based on remote sensing and footprint modelling. Agric For Meteorol 151(1):87-100

Ciais P, Sabine C, Bala G, et al (2013) Carbon and other biogeochemical cycles. In: Stocker TF, Qin D, Plattner G-K, et al. (eds) Climate change 2013: the physical science basis. Contribution of working group I to the fifth assessment report of the intergovernmental panel on climate change. Cambridge University Press, Cambridge, pp 465-570

Coleman DC (1973) Compartmental analysis of "Total Soil Respiration": an exploratory study. Oikos 24(3):361

Collalti A, Marconi S, Ibrom A et al (2016) Validation of 3DCMCC Forest Ecosystem Model (v.5.1) against eddy covariance data for 10 European forest sites. Geosci Model Dev 9: 479-504. doi:10.5194/gmd-9-479-2016

Cook BD, Davis KJ, Wang W, Desai A, Berger BW, Teclaw RM, Martin JG, Bolstad PV, Bakwin PS, Yi C, Heilman W (2004) Carbon exchange and venting anomalies in an upland deciduous forest in northern Wisconsin, USA. Agric For Meteorol 126(3-4):271-295. doi:10.1016/j.agrformet.2007.11.012

Cox PM, Pearson D, Booth BB et al (2013) Sensitivity of tropical carbon to climate change constrained by carbon dioxide variability. Nature 494:341-344. doi:10.1038/nature11882

Creelman C (2015) Biases of Sparse Data and Measurement Scheduling on Flux Estimates. Eosence Inc Tech Rep. doi:10.13140/RG.2.1.3797.1280

Cueva A, Bahn M, Litvak M et al (2015) A multisite analysis of temporal random errors in soil $\mathrm{CO}_{2}$ efflux. J Geophys Res Biogeosciences 120:737-751. doi:10.1002/2014JG002690

Curtis PS, Hanson PJ, Bolstad P et al (2002) Biometric and eddycovariance based estimates of annual carbon storage in five eastern North American deciduous forests. Agric For Meteorol 113:3-19. doi:10.1016/S0168-1923(02)00099-0

Czimczik CI, Trumbore SE, Carbone MS, Winston GC (2006) Changing sources of soil respiration with time since fire in a boreal forest. Glob Change Biol 12:957-971. doi:10.1111/ j.1365-2486.2006.01107.x

Davidson EA, Holbrook NM (2009) Is temporal variation of soil respiration linked to the phenology of photosynthesis? In: Noormets A (ed) Phenology of ecosystem processes. Springer New York, New York, pp. 187-199

Davidson EA, Savage KE, Trumbore SE, Borken W (2006) Vertical partitioning of $\mathrm{CO} 2$ production within a temperate forest soil. Glob Change Biol 12:944-956. doi:10.1111/ j.1365-2486.2005.01142.x

Desai AR, Richardson AD, Moffat AM, Kattge J, Hollinger DY, Barr A, Falge E, Noormets A, Papale D, Reichstein M, Stauch VJ (2008) Cross-site evaluation of eddy covariance GPP and RE decomposition techniques. Agric For Meteorol 148(6-7):821-838. doi:10.1016/j.agrformet.2007.11.012

Dietze MC, Lebauer DS, Kooper R (2013) On improving the communication between models and data: Communication between models and data. Plant Cell Environ 36:1575-1585. doi: 10.1111 pce. 12043 
Dijkstra FA, Carrillo Y, Pendall E, Morgan JA (2013) Rhizosphere priming: a nutrient perspective. Front Microbiol. doi:10.3389/ fmicb.2013.00216

Dunne JP, John JG, Adcroft AJ et al (2012) GFDL's ESM2 global coupled climate-carbon earth system models. Part I: physical formulation and baseline simulation characteristics. J Clim 25:6646-6665. doi:10.1175/JCLI-D-11-00560.1

Falge E, Baldocchi D, Olson R, Anthoni P, Aubinet M, Bernhofer C, Burba G, Ceulemans R, Clement R, Dolman H, Granier A, Gross P, Grünwald T, Hollinger D, Jensen N-O, Katul G, Keronen P, Kowalski A, Lai CT, Law BE, Meyers T, Moncrieff J, Moors E, Munger JW, Pilegaard K, Rannik Ü, Rebmann C, Suyker A, Tenhunen J, Tu K, Verma S, Vesala T, Wilson K, Wofsy S (2001) Gap filling strategies for long term energy flux data sets. Agric For Meteorol 107(1):71-77 doi:10.1016/S0168-1923(00)00235-5

Falge E, Tenhunen J, Baldocchi D, Aubinet M, Bakwin P, Berbigier P, Bernhofer C, Bonnefond J-M, Burba G, Clement R, Davis KJ, Elbers JA, Falk M, Goldstein AH, Grelle A, Granier A, Grünwald T, Guðmundsson J, Hollinger D, Janssens IA, Keronen P, Kowalski AS, Katul G, Law BE, Malhi Y, Meyers T, Monson RK, Moors E, Munger JW, Oechel W, Kyaw Tha Paw U, Pilegaard K, Rannik Ü, Rebmann C, Suyker A, Thorgeirsson H, Tirone G, Turnipseed A, Wilson K, Wofsy S (2002) Phase and amplitude of ecosystem carbon release and uptake potentials as derived from FLUXNET measurements. Agric For Meteorol 113(1-4):75-95

Finkelstein PL, Sims PF (2001) Sampling error in eddy correlation flux measurements. J Geophys Res Atmos 106(D4):35033509

Finzi AC, Abramoff RZ, Spiller KS et al (2015) Rhizosphere processes are quantitatively important components of terrestrial carbon and nutrient cycles. Glob Change Biol 21:20822094. doi: $10.1111 / \mathrm{gcb} .12816$

Foken T (2008) The energy balance closure problem: an overview. Ecol Appl 18(6):1351-1367

Foken T, Aubinet M, Finnigan JJ et al (2011) Results of a panel discussion about the energy balance closure correction for trace gases. Bull Am Meteorol Soc 92:ES13-ES18. doi:10.1175/2011BAMS3130.1

Franks SW, Beven KJ, Quinn PF, Wright IR (1997) On the sensitivity of soil-vegetation-atmosphere transfer (SVAT) schemes: equifinality and the problem of robust calibration. Agric For Meteorol 86:63-75. doi:10.1016/S0168-1923 (96)02421-5

Franssen HJH, Stöckli R, Lehner I et al (2010) Energy balance closure of eddy-covariance data: a multisite analysis for European FLUXNET stations. Agric For Meteorol 150: 1553-1567. doi:10.1016/j.agrformet.2010.08.005

Friedlingstein P, Cox P, Betts R et al (2006) Climate-carbon cycle feedback analysis: results from the $\mathrm{C}^{4} \mathrm{MIP}$ model intercomparison. J Clim 19:3337-3353. doi:10.1175/JCLI3800.1

Friedlingstein P, Meinshausen M, Arora VK et al (2014) Uncertainties in CMIP5 climate projections due to carbon cycle feedbacks. J Clim 27:511-526. doi:10.1175/JCLI-D12-00579.1

Gaudinski JB, Trumbore SE, Davidson EA, Zheng S (2000) Soil carbon cycling in a temperate forest: radiocarbon-based estimates of residence times, sequestration rates and partitioning of fluxes. Biogeochemistry 51:33-69
Giardina CP, Litton CM, Crow SE, Asner GP (2014) Warmingrelated increases in soil $\mathrm{CO} 2$ efflux are explained by increased below-ground carbon flux. Nat Clim Chang 4:822827. doi:10.1038/nclimate2322

Giasson M-A, Ellison AM, Bowden RD et al (2013) Soil respiration in a northeastern US temperate forest: a 22-year synthesis. Ecosphere 4:art140. doi:10.1890/ES13.00183.1

Gomez-Casanovas N, Anderson-Teixeira K, Zeri M et al (2013) Gap filling strategies and error in estimating annual soil respiration. Glob Change Biol 19:1941-1952. doi:10.1111/ gcb. 12127

Gough CM, Vogel CS, Schmid HP et al (2008) Multi-year convergence of biometric and meteorological estimates of forest carbon storage. Agric For Meteorol 148:158-170. doi:10.1016/j.agrformet.2007.08.004

Goulden ML, Munger JW, Fan S-M et al (1996) Measurements of carbon sequestration by long-term eddy covariance: methods and a critical evaluation of accuracy. Glob Change Biol 2: 169-182

Goulden ML, Mcmillan AMS, Winston GC et al (2011) Patterns of NPP, GPP, respiration, and NEP during boreal forest succession. Glob Change Biol 17:855-871. doi:10.1111/ j.1365-2486.2010.02274.x

Gower ST, Pongracic S, Landsberg JJ (1996) A Global Trend in Belowground Carbon Allocation: Can We Use the Relationship at Smaller Scales? Ecology 77:1750-1755. doi: $10.2307 / 2265780$

Graven HD (2015) Impact of fossil fuel emissions on atmospheric radiocarbon and various applications of radiocarbon over this century. Proc Natl Acad Sci 112:9542-9545. doi:10.1073/ pnas. 1504467112

Hahn V, Högberg P, Buchmann N (2006) 14C - a tool for separation of autotrophic and heterotrophic soil respiration. Glob Change Biol 12:972-982. doi:10.1111/j.13652486.2006.001143.x

Hanson PJ, Edwards NT, Garten CT, Andrews JA (2000) Separating root and soil microbial contributions to soil respiration: A review of methods and observations. Biogeochemistry 48: 115-146. doi:10.1023/A:1006244819642

Harmon ME, Bond-Lamberty B, Tang J, Vargas R (2011) Heterotrophic respiration in disturbed forests: A review with examples from North America. J Geophys Res. doi:10.1029/2010JG001495

Hartley IP, Garnett MH, Sommerkorn M et al (2012) A potential loss of carbon associated with greater plant growth in the European Arctic. Nat Clim Chang 2:875-879. doi:10.1038/ nclimate 1575

Hashimoto S (2012) A New Estimation of Global Soil Greenhouse Gas Fluxes Using a Simple Data-Oriented Model. PLoS One 7:e41962. doi:10.1371/journal.pone.0041962

Heinemeyer A, Hartley IP, Evans SP et al (2007) Forest soil $\mathrm{CO}_{2}$ flux: uncovering the contribution and environmental responses of ectomycorrhizas. Glob Change Biol 13:17861797. doi:10.1111/j.1365-2486.2007.01383.x

Heinemeyer A, Di Bene C, Lloyd AR et al (2011) Soil respiration: implications of the plant-soil continuum and respiration chamber collar-insertion depth on measurement and modelling of soil CO2 efflux rates in three ecosystems. Eur J Soil Sci 62:82-94. doi:10.1111/j.1365-2389.2010.01331.x

Heinemeyer A, Wilkinson M, Vargas R et al (2012) Exploring the "overflow tap" theory: linking forest soil $\mathrm{CO}_{2}$; fluxes and 
individual mycorrhizosphere components to photosynthesis. Biogeosciences 9:79-95. doi:10.5194/bg-9-79-2012

Herbst M, Bornemann L, Graf A et al (2012) A geostatistical approach to the field-scale pattern of heterotrophic soil CO2 emission using covariates. Biogeochemistry 111:377-392. doi:10.1007/s10533-011-9661-4

Hoffman FM, Randerson JT, Arora VK et al (2014) Causes and implications of persistent atmospheric carbon dioxide biases in Earth System Models. J Geophys Res Biogeosciences 119: 141-162. doi:10.1002/2013JG002381

Högberg P, Nordgren A, Buchmann N et al (2001) Large-scale forest girdling shows that current photosynthesis drives soil respiration. Nature 411:789-792. doi:10.1038/35081058

Hopkins F, Gonzalez-Meler MA, Flower CE et al (2013) Ecosystem-level controls on root-rhizosphere respiration. New Phytol 199:339-351. doi:10.1111/nph.12271

Hudiburg T, Law B, Turner DP et al (2009) Carbon dynamics of Oregon and Northern California forests and potential landbased carbon storage. Ecol Appl 19:163-180. doi:10.1890/ 07-2006.1

Hudiburg TW, Law BE, Thornton PE (2013) Evaluation and improvement of the Community Land Model (CLM4) in Oregon forests. Biogeosciences 10:453-470. doi:10.5194/ bg-10-453-2013

Janssens IA, Dieleman W, Luyssaert S, Subke J-A, Reichstein M, Ceulemans R, Ciais P, Dolman AJ, Grace J, Matteucci G, Papale D, Piao SL, Schulze E-D, Tang J, Law BE (2010) Reduction of forest soil respiration in response to nitrogen deposition. Nat Geosci 3(5):315-322. doi:10.1038/ngeo844

Jenkinson D, Poulton PR, Bryant C (2008) The turnover of organic carbon in sub-soils, Part 1. Natural and bomb radiocarbon in soil profiles from the Rothamsted long-term field experiments. Eur J Soil Sci 59:391-399. doi:10.1111/j.13652389.2008.01025.x

Keenan TF, Davidson E, Moffat AM et al (2012) Using model-data fusion to interpret past trends, and quantify uncertainties in future projections, of terrestrial ecosystem carbon cycling. Glob Change Biol 18:2555-2569. doi:10.1111/ j.1365-2486.2012.02684.x

Keenan TF, Davidson EA, Munger JW, Richardson AD (2013) Rate my data: quantifying the value of ecological data for the development of models of the terrestrial carbon cycle. Ecol Appl 23:273-286. doi:10.1890/12-0747.1

Kelley DI, Prentice IC, Harrison SP et al (2013) A comprehensive benchmarking system for evaluating global vegetation models. Biogeosciences 10:3313-3340. doi:10.5194/bg-103313-2013

Khomik M, Arain MA, McCaughey JH (2006) Temporal and spatial variability of soil respiration in a boreal mixedwood forest. Agric For Meteorol 140:244-256. doi:10.1016/j. agrformet.2006.08.006

Kicklighter DW, Melillo JM, Peterjohn WT et al (1994) Aspects of spatial and temporal aggregation in estimating regional carbon dioxide fluxes from temperate forest soils. J Geophys Res 99:1303. doi:10.1029/93JD02964

Kim D-G, Vargas R, Bond-Lamberty B, Turetsky MR (2012) Effects of soil rewetting and thawing on soil gas fluxes: a review of current literature and suggestions for future research. Biogeosciences 9:2459-2483. doi:10.5194/bg-92459-2012
Kira T, Shidei T (1967) Primary production and turnover of organic matter in different forest ecosystems of the western Pacific. Jpn J Ecol 17:70-87

Kosugi Y, Mitani T, Itoh M et al (2007) Spatial and temporal variation in soil respiration in a Southeast Asian tropical rainforest. Agric For Meteorol 147:35-47. doi:10.1016/j. agrformet.2007.06.005

Koven CD, Riley WJ, Torn MS et al (2013) The effect of vertically-resolved soil biogeochemistry and alternate soil $\mathrm{C}$ and $\mathrm{N}$ models on $\mathrm{C}$ dynamics of CLM4. Biogeosciences Discuss 10:7201-7256. doi:10.5194/bgd-10-7201-2013

Kreba SA, Coyne MS, McCulley RL, Wendroth OO (2013) spatial and temporal patterns of carbon dioxide flux in crop and grass land-use systems. Vadose Zone J 12. doi:10.2136/ vzj2013.01.0005

Kuppel S, Peylin P, Chevallier F et al (2012) Constraining a global ecosystem model with multi-site eddy-covariance data. Biogeosciences 9:3757-3776. doi:10.5194/bg-9-3757-2012

Kutsch W, Kolle O, Rebmann C et al (2008) Advection and resulting $\mathrm{CO} 2$ exchange uncertainty in a tall forest in central Germany. Ecol Appl 18:1391-1405

Kuzyakov Y (2006) Sources of CO2 efflux from soil and review of partitioning methods. Soil Biol Biochem 38:425-448. doi:10.1016/j.soilbio.2005.08.020

Lasslop G, Reichstein M, Papale D, Richardson AD, Arneth A, Barr A, Stoy P, Wohlfahrt G (2010) Separation of net ecosystem exchange into assimilation and respiration using a light response curve approach: critical issues and global evaluation. Glob Chang Biol 16(1):187-208

Lasslop G, Migliavacca M, Bohrer G, Reichstein M, Bahn M, Ibrom A, Jacobs C, Kolari P, Papale D, Vesala T, Wohlfahrt G, Cescatti A (2012) On the choice of the driving temperature for eddy-covariance carbon dioxide flux partitioning. Biogeosciences 9(12):5243-5259. doi:10.5194/bg-9-52432012

Lavigne MB, Ryan MG, Anderson DE et al (1997) Comparing nocturnal eddy covariance measurements to estimates of ecosystem respiration made by scaling chamber measurements at six coniferous boreal sites. J Geophys Res Atmospheres 102: 28977-28985. doi:10.1029/97JD01173

Lavoie M, Phillips CL, Risk D (2014) A practical approach for uncertainty quantification of high frequency soil respiration using Forced Diffusion chambers. J Geophys Res-Biogeosciences. doi:10.1002/2014JG002773

LeBauer DS, Wang D, Richter KT et al (2013) Facilitating feedbacks between field measurements and ecosystem models. Ecol Monogr 83:133-154. doi:10.1890/12-0137.1

Leon E, Vargas R, Bullock S et al (2014) Hot spots, hot moments, and spatio-temporal controls on soil $\mathrm{CO}_{2}$ efflux in a waterlimited ecosystem. Soil Biol Biochem. doi:10.1016/j.soilbio. 2014.05.029

Liptzin D, Silver WL, Detto M (2011) Temporal dynamics in soil oxygen and greenhouse gases in two humid tropical forests. Ecosystems 14:171-182. doi:10.1007/s10021-010-9402-x

Litton CM, Giardina CP (2008) Below-ground carbon flux and partitioning: global patterns and response to temperature. Funct Ecol 22:941-954. doi:10.1111/j.13652435.2008.01479.x

Litton CM, Raich JW, Ryan MG (2007) Carbon allocation in forest ecosystems. Glob Change Biol 13:2089-2109. doi:10.1111/j.1365-2486.2007.01420.x 
Loescher HW, Law BE, Mahrt L, Hollinger DY, Campbell J, Wofsy SC (2006) Uncertainties in, and interpretation of, carbon flux estimates using the eddy covariance technique. J Geophys Res 111(D21)

Lundegårdh H (1927) Carbon dioxide evolution of soil and crop growth. Soil Sci 23(6):417-453

Luo Y, Zhou X (2006) Soil respiration and the environment. Elsevier Academic Press, Amsterdam

Luo YQ, Randerson JT, Abramowitz G et al (2012) A framework for benchmarking land models. Biogeosciences 9:38573874. doi:10.5194/bg-9-3857-2012

Luo Y, Ahlström A, Allison SD, Batjes NH, Brovkin V, Carvalhais N, Chappell A, Ciais P, Davidson EA, Finzi A, Georgiou K, Guenet B, Hararuk O, Harden JW, He Y, Hopkins F, Jiang L, Koven C, Jackson RB, Jones CD, Lara MJ, Liang J, David McGuire A, Parton W, Peng C, Randerson JT, Salazar A, Sierra CA, Smith MJ, Tian H, Todd-Brown KEO, Torn M, van Groenigen KJ, Wang YP, West TO, Wei Y, Wieder WR, Xia J, Xu X, Xu X, Zhou T (2016) Toward more realistic projections of soil carbon dynamics by Earth system models. Glob Biogeochem Cycles 30(1):40-56

Luyssaert S, Inglima I, Jung $\mathrm{M}$ et al (2007) $\mathrm{CO}_{2}$ balance of boreal, temperate, and tropical forests derived from a global database. Glob Change Biol 13:2509-2537. doi:10.1111/j.13652486.2007.01439.x

Lynch DJ, Matamala R, Iversen CM et al (2013) Stored carbon partly fuels fine-root respiration but is not used for production of new fine roots. New Phytol 199:420-430. doi:10.1111/ nph. 12290

Maier M, Schack-Kirchner H (2014) Using the gradient method to determine soil gas flux: A review. Agric For Meteorol 192193:78-95. doi:10.1016/j.agrformet.2014.03.006

Martin JG, Bolstad PV (2009) Variation of soil respiration at three spatial scales: Components within measurements, intra-site variation and patterns on the landscape. Soil Biol Biochem 41:530-543. doi:10.1016/j.soilbio.2008.12.012

Martin JG, Bolstad PV, Norman JM (2004) A carbon dioxide flux generator for testing infrared gas analyzer based soil respiration systems. Soil Sci Soc Am J 68:514-518

Martin JG, Phillips CL, Schmidt A et al (2012) High-frequency analysis of the complex linkage between soil $\mathrm{CO} 2$ fluxes, photosynthesis and environmental variables. Tree Physiol 32: 49-64. doi:10.1093/treephys/tpr134

McClain ME, Boyer EW, Dent CL et al (2003) Biogeochemical hot spots and hot moments at the interface of terrestrial and aquatic ecosystems. Ecosystems 6:301-312. doi:10.1007 /s10021-003-0161-9

McFarlane KJ, Finzi AC, Nave L, Tang J (2014) Recommendations for belowground carbon data and measurements for the AmeriFlux network. Whitepaper solicited by the AmeriFlux Management Project, prepared for the Department of Energy Office of Biological and Envrionmental Research. http://ameriflux.lbl.gov/wpcontent/uploads/2014/11 / M c F a r l a n e _ e t_a $1_{-}$B e 1 o w g r o u n d C AmeriFluxwhitepaper2014.pdf

Medlyn BE, Robinson AP, Clement R, McMurtrie RE (2005) On the validation of models of forest $\mathrm{CO}_{2}$ exchange using eddy covariance data: some perils and pitfalls. Tree Physiol 25: 839-857. doi:10.1093/treephys/25.7.839

Medvigy D, Wofsy SC, Munger JW et al (2009) Mechanistic scaling of ecosystem function and dynamics in space and time: Ecosystem Demography model version 2. J Geophys Res. doi:10.1029/2008JG000812

Metzger S, Junkermann W, Mauder M et al (2013) Spatially explicit regionalization of airborne flux measurements using environmental response functions. Biogeosciences 10:21932217. doi:10.5194/bg-10-2193-2013

Mills CT, Slater GF, Dias RF et al (2013) The relative contribution of methanotrophs to microbial communities and carbon cycling in soil overlying a coal-bed methane seep. FEMS Microbiol Ecol 84:474-494. doi:10.1111/1574-6941.12079

Moffat AM, Papale D, Reichstein M et al (2007) Comprehensive comparison of gap-filling techniques for eddy covariance net carbon fluxes. Agric For Meteorol 147:209-232. doi:10.1016/j.agrformet.2007.08.011

Monson RK, Lipson DL, Burns SP, Turnipseed AA, Delany AC, Williams MW, Schmidt SK (2006) Winter forest soil respiration controlled by climate and microbial community composition. Nature 439(7077):711-714. doi:10.1038 /nature04555

Moyano F, Kutsch W, Schulze E (2007) Response of mycorrhizal, rhizosphere and soil basal respiration to temperature and photosynthesis in a barley field. Soil Biol Biochem 39:843853. doi:10.1016/j.soilbio.2006.10.001

Nickerson N, Risk D (2009) Physical controls on the isotopic composition of soil-respired CO2. J Geophys Res 114: G01013. doi:10.1029/2008JG000766

Odum EP (1969) The Strategy of Ecosystem Development. Science 164:262-270. doi:10.1126/science.164.3877.262

Ogle K, Pendall E (2015) Isotope partitioning of soil respiration: A Bayesian solution to accommodate multiple sources of variability: Bayesian isotope partitioning of fluxes. J Geophys Res Biogeosciences 120:221-236. doi:10.1002/2014 JG002794

Ohkubo S, Kosugi Y, Takanashi S, Mitani T, Tani M (2007) Comparison of the eddy covariance and automated closed chamber methods for evaluating nocturnal $\mathrm{CO} 2$ exchange in a Japanese cypress forest. Agric For Meteorol 142(1):50-65

Oikawa PY, Grantz DA, Chatterjee A et al (2014) Unifying soil respiration pulses, inhibition, and temperature hysteresis through dynamics of labile soil carbon and $\mathrm{O}_{2}$ : Soil $\mathrm{C}$ and $\mathrm{O} 2$ regulate soil respiration. J Geophys Res Biogeosciences 119:521-536. doi:10.1002/2013JG002434

Oleson KW, Lawrence DM, Bonan GB et al (2010) Technical description of version 4.0 of the community land model (CLM). National Center for Atmospheric Research, Boulder

Papale D, Reichstein M, Aubinet M et al (2006) Towards a standardized processing of Net Ecosystem Exchange measured with eddy covariance technique: algorithms and uncertainty estimation. Biogeosciences 3:571-583. doi:10.5194 /bg-3-571-2006

Parton WJ, Hanson PJ, Swanston C et al (2010) ForCent model development and testing using the Enriched Background Isotope Study experiment. J Geophys Res. doi:10.1029 /2009JG001193

Paustian K, Lehmann J, Ogle S et al (2016) Climate-smart soils. Nature 532:49-57. doi:10.1038/nature17174

Phillips SC, Varner RK, Frolking S et al (2010) Interannual, seasonal, and diel variation in soil respiraiton relative to ecosystem respiration at a wetland to upland slope at Harvard Forest. J Geophys Res 115:G02019. doi:10.1029/ 2008JG000858 
Phillips CL, Nickerson N, Risk D, Bond BJ (2011) Interpreting diel hysteresis between soil respiration and temperature. Glob Change Biol 17:515-527. doi:10.1111/ j.1365-2486.2010.02250.x

Phillips CL, Kluber LA, Martin JP et al (2012) Contributions of ectomycorrhizal fungal mats to forest soil respiration. Biogeosciences 9:1-12. doi:10.5194/bg-9-1-2012

Phillips CL, McFarlane KJ, Risk D, Desai AR (2013) Biological and physical influences on soil ${ }^{14} \mathrm{CO}_{2}$ seasonal dynamics in a temperate hardwood forest. Biogeosciences 10:7999-8012. doi:10.5194/bg-10-7999-2013

Pumpanen J, Kolari P, Ilvesniemi H et al (2004) Comparison of different chamber techniques for measuring soil $\mathrm{CO} 2$ efflux. Agric For Meteorol 123:159-176

Qiao N, Schaefer D, Blagodatskaya E et al (2014) Labile carbon retention compensates for $\mathrm{CO} 2$ released by priming in forest soils. Glob Change Biol 20:1943-1954

Raich JW, Nadelhoffer KJ (1989) Belowground Carbon Allocation in Forest Ecosystems: Global Trends. Ecology 70:1346-1354. doi:10.2307/1938194

Raich JW, Schlesinger WH (1992) The global carbon dioxide flux in soil respiration and its relationship to vegetation and climate. Tellus B 44:81-99. doi:10.1034/j.1600-0889.1992.t011-00001.x

Reichstein M, Beer C (2008) Soil respiration across scales: The importance of a model-data integration framework for data interpretation. J Plant Nutr Soil Sci 171:344-354. doi:10.1002/jpln.200700075

Rey A, Belelli-Marchesini L, Etiope G et al (2014) Partitioning the net ecosystem carbon balance of a semiarid steppe into biological and geological components. Biogeochemistry 118:83-101. doi:10.1007/s10533-013-9907-4

Richardson AD, Hollinger DY, Burba GG, Davis KJ, Flanagan LB, Katul GG, William Munger J, Ricciuto DM, Stoy PC, Suyker AE, Verma SB, Wofsy SC (2006) A multi-site analysis of random error in tower-based measurements of carbon and energy fluxes. Agric For Meteorol 136(1-2):1-18

Richardson AD, Williams M, Hollinger DY et al (2010) Estimating parameters of a forest ecosystem $\mathrm{C}$ model with measurements of stocks and fluxes as joint constraints. Oecologia 164:25-40. doi:10.1007/s00442-010-1628-y

Risk D, Nickerson N, Creelman C et al (2011) Forced diffusion soil flux: A new technique for continuous monitoring of soil gas efflux. Agric For Meteorol 151:1622-1631. doi:10.1016/ j.agrformet.2011.06.020

Risk D, Lee CK, MacIntyre C, Cary SC (2013a) First year-round record of Antarctic Dry Valley soil CO2 flux. Soil Biol Biochem 66:193-196. doi:10.1016/j.soilbio.2013.07.006

Risk D, McArthur G, Nickerson N et al (2013b) Bulk and isotopic characterization of biogenic $\mathrm{CO} 2$ sources and variability in the Weyburn injection area. Int J Greenh Gas Control 16: S263-S275. doi:10.1016/j.ijggc.2013.02.024

Riveros-Iregui DA, McGlynn BL (2009) Landscape structure control on soil $\mathrm{CO}_{2}$ efflux variability in complex terrain: Scaling from point observations to watershed scale fluxes. $\mathrm{J}$ Geophys Res. doi:10.1029/2008JG000885

Riveros-Iregui DA, Emanuel RE, Muth DJ et al (2007) Diurnal hysteresis between soil $\mathrm{CO}_{2}$ and soil temperature is controlled by soil water content. Geophys Res Lett. doi:10.1029/ 2007GL030938
Rodeghiero M, Cescatti A (2008) Spatial variability and optimal sampling strategy of soil respiration. For Ecol Manag 255: 106-112. doi:10.1016/j.foreco.2007.08.025

Romanak KD, Bennett PC, Yang C, Hovorka S (2012) Processbased approach to $\mathrm{CO}_{2}$ seepage detection by vadose zone gas monitoring at geologic $\mathrm{CO}_{2}$ storage sites. Geophys Res Lett 39(15)

Saiz G, Green C, Butterbach-Bahl K et al (2006) Seasonal and spatial variability of soil respiration in four Sitka spruce stands. Plant Soil 287:161-176. doi:10.1007/s11104-0069052-0

Savage K, Davidson EA, Richardson AD (2008) A conceptual and practical approach to data quality and analysis procedures for high-frequency soil respiration measurements. Funct Ecol 22:1000-1007. doi:10.1111/j.1365-2435.2008.01414.x

Savage K, Davidson EA, Richardson AD, Hollinger DY (2009) Three scales of temporal resolution from automated soil respiration measurements. Agric For Meteorol 149:20122021. doi:10.1016/j.agrformet.2009.07.008

Schimel D, Aubinet M, Finnegan J (2008) Eddy Flux measurements in difficult conditions ${ }^{1}$. Ecol Appl 18:1338-1339. doi:10.1890/07-2118.1

Schmid HP (2002) Footprint modeling for vegetation atmosphere exchange studies: a review and perspective. Agric For Meteorol 113(1-4):159-183. doi:10.1016/S0168-1923(02 )00107-7

Schmidt A, Hanson C, Chan WS, Law BE (2012) Empirical assessment of uncertainties of meteorological parameters and turbulent fluxes in the AmeriFlux network. J Geophys Res Biogeosci 117(G4):n/a-n/a

Schuur EAG, Vogel JG, Crummer KG et al (2009) The effect of permafrost thaw on old carbon release and net carbon exchange from tundra. Nature 459:556-559

Schwalm CR, Williams CA, Schaefer K et al (2010) A model-data intercomparison of $\mathrm{CO}_{2}$ exchange across North America: results from the North American Carbon Program site synthesis. J Geophys Res. doi:10.1029/2009JG001229

Serrano-Ortiz P, Roland M, Sanchez-Moral S et al (2010) Hidden, abiotic $\mathrm{CO} 2$ flows and gaseous reservoirs in the terrestrial carbon cycle: Review and perspectives. Agric For Meteorol 150:321-329. doi:10.1016/j.agrformet.2010.01.002

Shanhun FL, Almond PC, Clough TJ, Smith CMS (2012) Abiotic processes dominate $\mathrm{CO} 2$ fluxes in Antarctic soils. Soil Biol Biochem 53:99-111. doi:10.1016/j.soilbio.2012.04.027

Shao P, Zeng X, Moore DJP, Zeng X (2013) Soil microbial respiration from observations and Earth System Models. Environ Res Lett 8(3):034034

Sierra CA, Trumbore SE, Davidson EA et al (2012) Predicting decadal trends and transient responses of radiocarbon storage and fluxes in a temperate forest soil. Biogeosciences 9:30133028. doi:10.5194/bg-9-3013-2012

Snell HSK, Robinson D, Midwood AJ (2014) Minimising methodological biases to improve the accuracy of partitioning soil respiration using natural abundance ${ }^{13} \mathrm{C}$ : Methods in partitioning soil respiration using natural abundance ${ }^{13} \mathrm{C}$. Rapid Commun Mass Spectrom 28:2341-2351. doi:10.1002/rcm.7017

Speckman HN, Frank JM, Bradford JB et al (2015) Forest ecosystem respiration estimated from eddy covariance and chamber measurements under high turbulence and 
substantial tree mortality from bark beetles. Glob Change Biol 21:708-721. doi:10.1111/gcb.12731

Stoy PC, Mauder M, Foken T et al (2013) A data-driven analysis of energy balance closure across FLUXNET research sites: The role of landscape scale heterogeneity. Agric For Meteorol 171-172:137-152. doi:10.1016/j.agrformet.2012.11.004

Stoyan H, De-Polli H, Bohm S et al (2000) Spatial heterogeneity of soil respiration and related properties at the plant scale. Plant Soil 222:203-214

Subke J-A, Inglima I, Francesca Cotrufo M (2006) Trends and methodological impacts in soil $\mathrm{CO}_{2}$ efflux partitioning: a metaanalytical review. Glob Change Biol 12:921-943. doi:10.1111/j.1365-2486.2006.01117.x

Takle ES, Massman WJ, Brandle JR et al (2004) Influence of high-frequency ambient pressure pumping on carbon dioxide efflux from soil. Agric For Meteorol 124:193-206. doi:10.1016/j.agrformet.2004.01.014

Tang J, Baldocchi DD (2005) Spatial-temporal variation in soil respiration in an oak-grass savanna ecosystem in California and its partitioning into autotrophic and heterotrophic components. Biogeochemistry 73:183-207. doi:10.1007/s10533004-5889-6

Tang JY, Baldocchi DD, Qi Y, Xu L (2003) Assessing soil CO2 efflux using continuous measurements of $\mathrm{CO} 2$ profiles in soils with smal solid-state sensors. Agric For Meteorol 118:207-220

Tang J, Baldocchi DD, Xu L (2005) Tree photosynthesis modulates soil respiration on a diurnal time scale. Glob Change Biol 11:1298-1304. doi:10.1111/j.1365-2486.2005.00978.x

Tang J, Bolstad PV, Desai AR et al (2008) Ecosystem respiration and its components in an old-growth forest in the Great Lakes region of the United States. Agric For Meteorol 148:171185. doi:10.1016/j.agrformet.2007.08.008

Teixeira DDB, da Bicalho ES, Panosso AR et al (2013) Spatial variability of soil $\mathrm{CO} 2$ emission in a sugarcane area characterized by secondary information. Sci Agric 70:195-203. doi:10.1590/S0103-90162013000300008

Thomas CK, Martin JG, Law BE, Davis K (2013) Toward biologically meaningful net carbon exchange estimates for tall, dense canopies: Multi-level eddy covariance observations and canopy coupling regimes in a mature Douglas-fir forest in Oregon. Agric For Meteorol 173:14-27. doi:10.1016/j. agrformet.2013.01.001

Thomey ML, Collins SL, Vargas R et al (2011) Effect of precipitation variability on net primary production and soil respiration in a Chihuahuan Desert grassland. Glob Change Biol 17: 1505-1515. doi:10.1111/j.1365-2486.2010.02363.x

Todd-Brown KEO, Hopkinds FM, Kivlin SN et al (2012) A framework for representing microbial decomposition in coupled climate models. Biogeochemistry 109:19-33. doi:10.1007/s10533-011-9635-6

Todd-Brown KEO, Randerson JT, Post WM et al (2013) Causes of variation in soil carbon simulations from CMIP5 Earth system models and comparison with observations. Biogeosciences 10:1717-1736. doi:10.5194/bg-10-1717-2013

Todd-Brown KEO, Randerson JT, Hopkins F et al (2014) Changes in soil organic carbon storage predicted by Earth system models during the twenty-first century. Biogeosciences 11: 2341-2356. doi:10.5194/bg-11-2341-2014

Trumbore SE (2000) Age of soil organic matter and soil respiration: radiocarbon constraints on belowground $\mathrm{C}$ dynamics. Ecol Appl 10:399-411
Trumbore SE (2009) Radiocarbon and soil carbon dynamics. Annu Rev Earth Planet Sci 37:47-66. doi:10.1146/annurev. earth.36.031207.124300

Turcu VE, Jones SB, Or D (2005) Continuous soil carbon dioxide and oxygen measurements and estimation of gradient-based gaseous flux. Vadose Zone J 4:1161. doi:10.2136/vzj2004.0164

Turpin HW (1920) The carbon dioxide content of the soil air. Cornell University Agricultural Experiment Station Memoir

Van Gorsel E, Leuning R, Cleugh HA et al (2007) Nocturnal carbon efflux: reconciliation of eddy covariance and chamber measurements using an alternative to the $\mathrm{u} *$-threshold filtering technique. Tellus B 59:397-403. doi:10.1111/ j.1600-0889.2007.00252.x

Van Gorsel E, Delpierre N, Leuning R et al (2009) Estimating nocturnal ecosystem respiration from the vertical turbulent flux and change in storage of $\mathrm{CO}_{2}$. Agric For Meteorol 149: 1919-1930. doi:10.1016/j.agrformet.2009.06.020

Vargas R, Allen MF (2008) Dynamics of fine root, fungal rhizomorphs, and soil respiration in a mixed temperate forest: integrating sensors and observations. Vadose Zone J 7:10551064. doi:10.2136/vzj2007.0138

Vargas, R., Leon, E. (2015) CMS: Soil $\mathrm{CO}_{2}$ Efflux and Properties, Site Vegetation Measurements, Mexico, 2011-2012. doi:10.3334/ORNLDAAC/1298

Vargas R, Baldocchi DD, Allen MF et al (2010a) Looking deeper into the soil: biophysical controls and seasonal lags of soil CO2 production and efflux. Ecol Appl 20:1569-1582. doi:10.1890/09-0693.1

Vargas R, Detto M, Baldocchi DD, Allen MF (2010b) Multiscale analysis of temporal variability of soil $\mathrm{CO}_{2}$ production as influenced by weather and vegetation. Glob Change Biol 16: 1589-1605. doi:10.1111/j.1365-2486.2009.02111.x

Vargas R, Baldocchi DD, Bahn M et al (2011a) On the multitemporal correlation between photosynthesis and soil $\mathrm{CO} 2$ efflux: reconciling lags and observations. New Phytol 191: 1006-1017. doi:10.1111/j.1469-8137.2011.03771.x

Vargas R, Carbone MS, Reichstein M, Baldocchi DD (2011b) Frontiers and challenges in soil respiration research. Biogeochemistry 102:1-13. doi:10.1007/s10533-010-9462-1

Vargas R, Collins SL, Thomey ML et al (2012) Precipitation variability and fire influence the temporal dynamics of soil CO2 efflux in an arid grassland. Glob Change Biol 18:14011411. doi:10.1111/j.1365-2486.2011.02628.x

Vicca S, Bahn M, Estiarte M et al (2014) Can current moisture responses predict soil $\mathrm{CO}_{2}$ efflux under altered precipitation regimes? A synthesis of manipulation experiments. Biogeosciences 11:2991-3013. doi:10.5194/bg-11-2991-2014

Viveiros F, Ferreira T, Cabral Vieira J et al (2008) Environmental influences on soil $\mathrm{CO}_{2}$ degassing at Furnas and Fogo volcanoes (São Miguel Island, Azores archipelago). J Volcanol Geotherm Res 177:883-893. doi:10.1016/j.jvolgeores.2008.07.005

Wang X, Liu L, Piao S et al (2014) Soil respiration under climate warming: differential response of heterotrophic and autotrophic respiration. Glob Change Biol 20:3229-3237. doi: $10.1111 / \mathrm{gcb} .12620$

Wehr R, Munger JW, McManus JB, Nelson DD, Zahniser MS, Davidson EA, Wofsy SC, Saleska SR (2016) Seasonality of temperate forest photosynthesis and daytime respiration. Nature 534(7609):680-683 
Werner C, Brantley S (2003) $\mathrm{CO}_{2}$ emissions from the Yellowstone volcanic system: yellowstone $\mathrm{CO}_{2}$ emissions. Geochem Geophys Geosystems 4. doi:10.1029/2002GC000473

Whitman T, Lehmann J (2015) A dual-isotope approach to allow conclusive partitioning between three sources. Nat Commun 6:8708. doi: $10.1038 /$ ncomms 9708

Wieder WR, Bonan GB, Allison SD (2013) Global soil carbon projections are improved by modelling microbial processes. Nat Clim Chang 3:909-912. doi:10.1038/nclimate1951

Wilkinson M, Gilfillan SVM, Haszeldine RS, Ballentine CJ (2010) Plumbing the depths: Testing natural tracers of subsurface $\mathrm{CO}_{2}$ origin and migration, Utah. In: Grobe M, Pashin JC, Dodge RL (eds) Carbon dioxide sequestration in geological media-State of the science. AAPG, pp 619-634

Williams M, Schwarz PA, Law BE et al (2005) An improved analysis of forest carbon dynamics using data assimilation. Glob Change Biol 11:89-105. doi:10.1111/j.1365-2486.2004.00891.x

Williams M, Richardson AD, Reichstein M et al (2009) Improving land surface models with FLUXNET data. Biogeosciences 6: 1341-1359. doi:10.5194/bg-6-1341-2009

Wutzler T, Reichstein M (2007) Soils apart from equilibrium: consequences for soil carbon balance modelling. Biogeosciences 4:125-136. doi:10.5194/bg-4-125-2007

$\mathrm{Xu} \mathrm{L}$, Baldocchi DD (2004) Seasonal variation in carbon dioxide exchange over a Mediterranean annual grassland in California. Agric For Meteorol 123:79-96. doi:10.1016/ j.agrformet.2003.10.004
Xu K, Metzger S, Desai AR (2017) Upscaling tower-observed turbulent exchange at fine spatio-temporal resolution using environmental response functions. Agric For Meteorol 232: 10-22. doi:10.1016/j.agrformet.2016.07.019

Zeeman MJ, Eugster W, Thomas CK (2012) Concurrency of Coherent Structures and Conditionally Sampled Daytime Sub-canopy Respiration. Bound-Layer Meteorol 146:1-15. doi:10.1007/s10546-012-9745-2

Zhang Q, Katul GG, Oren R et al (2015) The hysteresis response of soil $\mathrm{CO}_{2}$ concentration and soil respiration to soil temperature. J Geophys Res Biogeosciences 120: 1605-1618. doi:10.1002/2015JG003047

Zhou T, Shi P, Hui D, Luo Y (2009) Global pattern of temperature sensitivity of soil heterotrophic respiration $\left(\mathrm{Q}_{10}\right)$ and its implications for carbon-climate feedback. J Geophys Res. doi: $10.1029 / 2008 J G 000850$

Zhou L, Zhou X, Shao J et al (2016) Interactive effects of global change factors on soil respiration and its components: a metaanalysis. Glob Change Biol n/a-n/a. doi:10.1111/gcb.13253

Zhu B, Cheng W (2011) Rhizosphere priming effect increases the temperature sensitivity of soil organic matter decomposition. Glob Chnge Biol 17:2172-2183. doi:10.1111/ j.1365-2486.2010.02354.x

Zobitz JM, Moore DJP, Sacks WJ et al (2008) Integration of Processbased Soil Respiration Models with Whole-Ecosystem CO2 Measurements. Ecosystems 11:250-269. doi:10.1007/s10021007-9120-1 